\title{
INDKOMSTPOLITIK OG KAPITALAKKUMULATION I DANMARK
}

Nils Bredsdorff, Jens Brinch og Leif Hansen

\section{INDLEDNING}

I foråret 1975 ophøjede den socialdemokratiske regering en skitse til en mæglingsskitse til lov og forlængede dermed i realiteten overenskomsterne uændret. Hermed var der for første gang siden 1963 foretaget et egentligt indkomstpolitisk indgreb og som det senere viste sig, var det kun det første.

Ved regeringserklæringen i efteråret 1976 og det senere diktat om 6-\%rammen ved overenskomsten i 1977 og de fremsatte erklæringer om denne lønrammes fortsættelse udover næste frist ved overenskomsten i 1979, er den statslige indkomstpolitik blevet et ligeså tydeligt banner for den socialdemokratiske styring af det kapitalistiske samfund i sidste halvdel af 70'erne, som den keynesianske ekspansive finanspolitik var det for tresserne.

Men indkomstpolitikken har jo ellers været diskuteret og proklameret $\mathrm{i}$ Danmark siden tressernes begyndelse og i Europa siden 2. Verdenskrigs afslutning. I de internationale $\varnothing$ konomiske organers jævnlige analyser og anbefalinger til de nationale regeringer har indkomstpolitikkens nødvendighed været det bestandige omkvæd siden midten af tresserne. Mens den borgerlige $\varnothing$ konomis ypperstepræster diskuterede og raffinerede analysen af indkomstpolitikken og politikplanlæggerne fremlagde den ene mere snedige plan efter den anden, så fungerede den borgerlige økonomi i Danmark i samme tidsrum fint uden disse indgreb. 
At konstatere, at der ikke har været ført indkomstpolitik i Danmark med undtagelse af kriseperiode fra 74 og at satse på at undersøge baggrunden herfor, er ikke det samme som at sige, at der ikke har været politiske kræfter, som $\varnothing$ nskede den gennemført, eller at kampen imod disse kræfter er spildte vejrmøllekampe. Vigtigere end alle de uklare begreber, som den borgerlige $\varnothing$ konomi kan diske op med i forbindelse med indkomstpolitikken, er det, at de indkomstpolitiske fors $\emptyset \mathrm{g}$ som blev lavet af både SD og VKR-regeringen i løbet af tresserne skabte et stadig klarere indtryk af, at indkomstpolitikken trods alle de ideologiske falbelader var rettet mod lønnen. Kulminationen af denne opfattelse var majstrejkerne i 1974, men krisen og massearbejdsløsheden skabte en situation, hvor SD efterhånden åbent kunne føre Hartlingregeringens politik igennem uden større problemer. Det er nu erkendt, at der er tale om lønpolitik, men SD dækker sig ind med henvisning til »den nationale katastrofesituation « og sammenkædningen med ØD. Indkomstpolitikken forsøges frigjort fra den hørm af arbejdsgiverpolitik, som altid har hængt over den og fors $\varnothing$ ges vendt til et positivt ladet begreb.

Mens de borgerlige og socialdemokratiske $\varnothing$ konomer således fors $\varnothing$ ger at få indkomstpolitikken til at tage sig ud som en teknisk formel, som blot skal »supplere « statsmagtens andre $\varnothing$ konomiske teknikker som finans- og pengepolitikken uden dog alligevel at kunne »afpolitisere « denne politikform, indeholder begrebet indkomstpolitik stadig en lang række politiskideologiske elementer, som det er vigtigt at få undersøgt for at kunne vurdere arbejderklassens reaktionsmuligheder under krisen og det socialdemokratiske styre.

Eller sagt på en anden måde: Når det er vigtigt at behandle de danske indkomstpolitiske erfaringer, og når det kan forsvares at gøre dette løsrevet fra helheden af socialdemokratisk stabilitetspolitik, så er det fordi indkomstpolitikken i højere grad end andre statslige politikfelter i denne stabilitetspolitik f.eks. arbejdsmarkeds-, struktur-, investeringsog rentepolitik og finanspolitik indeholder konfrontations- og konfliktpotentiel overfor arbejderklassen og samtidig i selve krisesituationen bliver tvingende nødvendig at få gennemført.

Forholdet til fagbevægelsen er det centrale politisk- $\varnothing$ konomiske problem for alle borgerlige teoretikere og politikere, der beskæftiger sig med indkomstpolitik, hvor hovedspørgsmålet er: Kan fagbevægelsen integreres i politikformuleringen og effektueringen, eller er fagbevægelsens funktion som interesseorganisation i sig selv en hindring for dette?

Den historieløshed som præger et sådant spørgsmål - eller rettere den manglende indsigt i fagforeningernes funktion i den kapitalistiske akkumulationsproces' udvikling, som det udtrykker - er imidlertid ikke enestående for borgerskabets spåmænd. Integrations- og korporativismeteorierne på venstre- 
fløjen opererer i virkeligheden med samme hoved- og historieløse begreber, som overser indkomstpolitikkens og hele stabilitetspolitikkens eksistens betingelser og kommer derfor til at fastfryse og generalisere konkrete historiske fagforeningsstrategier som almene historiske tendenser. Kun en undersøgelse af den danske kapitalismes akkumulationsmæssige forudsætninger og den danske krisepolitiks eksistensbetingelser kan danne grundlaget for en vurdering af fagbevægelsens reaktionsmuligheder og indkomstpolitikkens og den socialdemokratiske krisemanagements muligheder. ${ }^{1}$

Ud fra disse overvejelser har vi fundet det nødvendigt at forsøge en afklaring af indkomstpolitikkens rolle i Danmark siden tressernes begyndelse. Vi vil først forsøge at afgrænse indkomstpolitik-begrebet fra andre statslige politikker og fra den upræcise brug som ses i den indkomstpolitiske debat. Dernæst vil vi undersøge det akkumulationsmæssige grundlag for den danske $\varnothing$ konomiske udvikling og de politiske og historiske forudsætninger for den danske indkomstpolitik. Som et afgørende element heri vil vi gå nærmere ind på den fagforeningsmæssige lønpolitik, som vi anser for en af de vigtigste forudsætninger for den specielle danske indkomstpolitik, og endelig vil vi se på den indkomstpolitiske udvikling fra 1960 og fremefter.

\section{Diskussion af begrebet indkomstpolitik}

For at illustrere forskellighederne i afgrænsningen af indkomstpolitikbegrebet, skal vi kort se på to typer af indkomstpolitikbestemmelser: en tænksom nationaløkonomisk og en politøkonomisk, repræsenteret ved hhv. Anne Romanis Braun ${ }^{2}$ og Willi Semmler og Jürgen Hoffmann ${ }^{3}$. Vi skal sammenligne de to typer med hensyn til indkomstpolitikkens formål, dens form og dens politikfelt.

A.R. Braun definerer indkomstpolitik således:

»Begrebet indkomstpolitik bruges almindeligvis til at betegne specifikke midler til at dæmpe den takt med hvilken pengeindkomsterne stiger, ved at styre og begrænse forretningslivets og fagbevægelsens, funktionærernes og

1. Jvf. diskussionen i Erling Havn: Om fagforeninger og lønpolitik, Kbh. 1977, p. 7 ff.

2. Anne Romanis Braun: The role of incomes policy in industrial countries since world war II, i: IMF Staff Papers, march 1975.

3. J.Hoffmann og W.Semmler: Kapitalreproduktion og indkomstpolitik, i Kurasje nr. 14. Forkortet $\mathrm{i}$ det følgende med $\mathrm{S} / \mathrm{H}$. 
andre gruppers udnyttelse af markedskræfterne. Indkomstpolitik defineres oftest som en regerings planlagte intervention i prisdannelsesprocessen på arbejdskraft og varer, med det formål at hindre pengeindkomsterne i at stige hurtigere end væksten i nationalindkomsten i faste priser.

Imidlertid er det ønskeligt også at inddrage de planlagte virkninger, der skabes af organisationerne og den private sektor på nationalt plan uden regeringsindgreb. I et system af koordinerede lønforhandlinger er den centrale fagbevægelse og arbejdsgiverorganisation stillet overfor nødvendigheden af en indkomstpolitik, da de må sætte deres beslutninger i forhold til den generelle $\varnothing$ konomiske situation og konjunkturerne. $\ll^{4}$

Ud over denne betragtning, hvor indkomstpolitikkens fordelingspolitiske aspekt - indkomstpolitik skal forhindre kapital og lønarbejde i at udnytte markedssituationen til at opnå prisstigninger på hver deres varer - fremhæves også, at indkomstpolitik er den institutionaliserede indflydelse på prisfastsættelsen for hhv. arbejde og kapitalistisk producerede varer.

Sammenfattende anføres, at denne opfattelse af indkomstpolitik betyder, at den især må betragtes som et »antiinflationært middel«. Formålet med indkomstpolitikken er således inflationsbekæmpelse, formen er en institutionalisering af prisdannelsen og den politikform, som i særlig grad aktiveres, er fordelingspolitikken. Anne R. Braun er ikke ene om denne opfattelse af indkomstpolitikken. ${ }^{5}$ Det er faktisk en generel nationaløkonomisk opfattelse af problemerne i 1960'erne. Indkomstpolitikken bliver nødvendig, fordi markedsforholdene (den høje beskæftigelse, den permanente høje efterspørgsel) skaber mulighed for prisstigninger, der truer den $\varnothing$ konomiske stabilitet.

Når Braun lægger vægten på de fordelingspolitiske aspekter, sker det naturligvis dels udfra hendes nationaløkonomiske forståelse af den økonomiske udvikling: en grundlæggende harmonisk proces med tilfældige historiske forstyrrelser eller manglende balancer, og dels ud fra en »ikke- $\varnothing$ konomisk « forståelse af den økonomiske politiks nødvendige legitimitetsbehov. Indkomstpolitik er i denne lidt mere politikbevidste nationaløkonomiske forståelse ikke alene lønpolitik, men også pris- og avancepolitik, altså mere generel fordelingspolitik, både fordi dette er i overensstemmelse med »økonomiens princip« og fordi andre måder at styre økonomien tilbage til balancesituationen på er urealisable.

Derfor er det også naturligt for hende ud over focuseringen på opretholdelse af fri konkurrence på markedet - dvs. undgå udnyttelse af forstyrrelserne -

4. Braun op.cit. p. $1 \mathrm{f}$.

5. Jvf. f.eks. E.C.E.: Incomes in postwar Europe, Genua 1967. OECDs mange publikationer om indkomstpolitik fra slutningen af tresserne forfægter samme standpunkt. 
at fremhæve institutionaliseringen af prisdannelsen. Hele udgangspunktet $\mathrm{i}$ analysen er styringsproblemerne. Problemerne anskues med statens øjne og svarer på spørgsmålet om, hvorledes man kan undgå disse prisstigninger. Svaret er enten statslig prisfastsættelse, hvilket er problematisk i et frit, demokratisk samfund, eller også en institutionalisering af prisdannelsen, dvs. indirekte styring og kontrol.

Vi har trukket Braun frem her, fordi vi mener, at der ligger en række problemer omkring institutionaliseringen af prisdannelsen. Ikke i de former, som Braun opfatter dem, men som elementer i en udviklet reformkapitalistisk strategi, en socialdemokratisk udviklingstendens, som har samfundsmæssig realitet og effekt i Skandinavien. Vi mener også, at Braun dermed peger på et problemfelt, som udelades hos Semmler og Hoffmann, hvis analyse til gengæld har mange andre fordele. Hvor Braun tager sit udgangspunkt i politikfeltets styringsproblemer, tager Semmler og Hoffmann deres udgangspunkt i skrankerne for den fortsatte merværdi- eller profitproduktion.

Hos Semmler og Hoffmann fremhæves, at indkomstpolitikken ene og alene er en lønpolitik (politikfeltet), fordi der i den modificerede krisecyklus opstår en nødvendighed af en permanent ydre begrænsning af arbejdslønnen:

»Det sker i historiske faser, hvor de cykliske kriser på grund af almen overakkumulation ikke længere er i stand til at opfylde deres 'funktion', som er at skabe grundlaget for et nyt opsving og hvor den statslige 'fuldbeskæftigelsespolitik' derfor må sikre en vellykket akkumulation. En kontraktionsproces skal forhindres; akkumulationen skal fastholdes som 'quasiboom' (Keynes) ved hjælp af udvidet brug af penge- og finanspolitik. En permanent ydre begransning af lфnnen er klart nфdvendig, når man anvender disse midler. ${ }^{6}$

Indkomstpolitikken rettes således udelukkende mod arbejdslønnen. Dens formål er forsøgsvis kriseovervindelse, hvilket forudsætter »en passende større merværdi og dermed også modsvarende (relativ) lavere løn « ${ }^{7}$. Dens formål er dermed også bestemt, nemlig som forøgelse af merværdiraten. Den eneste instans, der kan fremkalde denne ydre begrænsning af arbejdslønnen for at forøge merværdiraten, er den kapitalistiske stat. Efter sin form bliver der tale om et ydre statsligt indgreb i løndannelsen.

På denne baggrund bestemmer Semmler og Hoffmann teoretisk indkomstpolitikkens indflydelse på profitproduktion og kapitaliseringen af profit og finder frem til at indkomstpolitikken historisk i efterkrigstiden har eksisteret i 5 forskellige typer:

6. Hoffmann og Semmler op.cit. p. 42.

7. Ibid. p. 43. 
I lønbegrænsning i form af lønstop, prisstop eller løn- og prisstop

II lønbegrænsning i form af kobling mellem lønstigning og pengeværdiforringelse (indeksregulering)

III lønbegrænsning i form af kobling mellem lønudvikling og produktivitetsudvikling

IV lønbegrænsning i form af kobling mellem lønudvikling og udviklingen i såvel priser som produktivitet

V lønbegrænsning i form af at lønnen bestemmes residualt, dvs. efter at kapitalen forlods har fået den profitmasse, som er nødvendig for at garantere en fortsat akkumulation.

Uanset hvilken af de fem typer, der er tale om, vil effekten altid være en for$\emptyset$ gelse af profitmassen, evt. en stigende merværdirate, men selvfølgelig forskellige stigningstakter for de fem forskellige typer.

Vi er enige med Semmler og Hoffmann i deres akkumulationsteoretiske udgangspunkt. Med basis i kapitalens modsigelsesfulde bevægelse i akkumulationsprocessen kan de netop vise, hvornår arbejdslønnens udvikling aktualiserer krisetendenserne samtidig med at arbejdslønnen alt $\mathrm{i}$ alt er den afhængige faktor. Men selv om vi er helt på linje med S/H i dette udgangspunkt, finder vi alligevel, at deres indkomstpolitiktyper ikke er udtømmende bestemt.

Hovedproblemet ligger omkring den indkomstpolitiktype, som de kalder den fjerde, altså der, hvor arbejdslønnens udvikling er bundet til pris- og produktivitetsudvikling. For det første gælder her, at denne indkomstpolitik egentlig ikke er særlig effektiv, set ud fra dens formål: merværdirateforøgelse. Den vil maksimalt kunne forøge udbytningsraten med det efterslæb, som der konkret måtte være i pristals- og produktivitetsdækning i arbejdslønnen. Set med arbejderklassens $\varnothing$ jne, vil denne form for indkomstpolitik altid være at foretrække, fordi den vil kunne fastfryse udbytningsraten. Det betyder, at det under visse omstændigheder endda vil kunne blive et offensivt mål for fagbevægelsen at få indført en lønbegrænsning i præcis denne form. Når man betragter det ud fra formålet med indkomstpolitikken, må der således være en række særlige omstændigheder, der nationalt og politisk forhindrer staten i at gennemføre mere målrettede indkomstpolitikformer. Særlige konjunkturelle omstændigheder eller en særlig stærk fagbevægelse kan gøre det muligt for staten at nøjes med denne type indkomstpolitik. Karakteristisk for $\mathrm{S} / \mathrm{Hs}$ artikel, er at den er ualmindeligt vag og upræcis på netop dette punkt. De anfører kun betragtninger, der gælder helt generelt: nemlig at selv en konstant eller stigende lønkvote udmærket kan dække over en stigende udbytningsrate.

I forhold til Semmler og Hoffmanns afgrænsning vil vi nærmest formulere den modsatte sammenhæng: at en »lønpolitik«, der effektivt binder arbejdsløn- 
nens udvikling til prisudvikling og produktivitetsstigning, i bestemte perioder er i stand til at overflødiggøre en egentlig indkomstpolitik, forstået som ydre statslige indgreb i løndannelsen. I modsætning til Semmler og Hoffmann vil vi således ikke betragte den fjerde indkomstpolitiktype som indkomstpolitik (= lønpolitik, lønkontrol), men snarere som en institutionalisering af løndannelsen, der overflødigg ør direkte statsindgreb og dermed undgår de legitimationsproblemer, som altid vil ledsage statslige lønstyringsforsøg.

Den fjerde type udfyldes gennem en institutionalisering af lønudviklingen jfr. A.R. Braun tidligere - som kan være støttet og ønsket, initieret eller viderebearbejdet af staten. Den er prototypen på den veludviklede, skandinaviske reformismes form for lønstyring. Dens forudsætninger er dermed dels af politisk art (den skandinaviske, socialdemokratiske udformning af forholdet mellem stat og fagbevægelse), dels af konjunkturel art (tidsforskudte krisecykler), dels betinget af den reformistiske kobling af lønpolitik, konjunkturpolitik, arbejdsmarkedspolitik mv. - men vel at mærke en kobling, som langt hen ad vejen overflødigg ør de direkte statslige lønindgreb.

Denne ændring af Semmler og Hoffmanns bestemmelse gælder ikke kun for den 4. type af lønstyring. Kritikken rammer lidt bredere i deres selvmodsigelser omkring bestemmelsen af indkomstpolitikkens formål og dens politikform, fordi der tilsyneladende sker en sammenblanding her. I det historiske afsnit i deres artikel hedder det f.eks. at de forskellige indkomstpolitiktyper forekommer i forskellige akkumulationsfaser i den vesteuropæiske kapitalismes efterkrigsudvikling. Således er det generelle billede i den allerførste akkumulationsfase umiddelbart efter krigen, at den indkomstpolitiske regulering indholdsmæssigt er type V, hvor arbejdslønnen er residualkategori, men at den kan sættes igennem uden ydre tvangsindgreb som en følge af den høje arbejdsløshed (med Holland som den eneste undtagelse). Det er indlysende, at den lønpolitik, der er fremherskende, indholdsmæssigt fastholder arbejdslønnen som en residualt bestemt størrelse. Men det er lige så indlysende, at det netop ikke - og det fremhæver $\mathrm{S} / \mathrm{H}$ endda selv - formmæssigt reguleres gennem ydre statslige tvangsindgreb. Akkumulation og krig og fascisme og splittelse i arbejderbevægelsen og meget mere betyder netop, at arbejdslønnen forholder sig residualt til akkumulationens profitbehov uden statslige tvangsindgreb.

Ud fra Semmler og Hoffmanns bestemmelse af indkomstpolitikken som de ydre statslige tvangsindgreb i løndannelsen er der således snarere tale om fraværet af en indkomstpolitik samtidig med, at arbejdslønnen indholdsmæssigt fastholdes i deres femte indkomstpolitiktype. Det interessante spørgsmål må så blive hvornår og under hvilke betingelser arbejdslønnens udvikling kan styres institutionelt dvs. uden statslig indkomstpolitik, og hvornår den kun kan styres som direkte statsligt politikfelt. 
Her kommer en række nationale forskelligheder ind i betragtningen, og vores artikel skal læses som et forsøg på at bestemme de særtræk i den danske kapitalisme og dens politiske udformning, der i bestemte perioder overflødiggør lønstyring som direkte statsaktivitet og som i bestemte faser/perioder også nødvendigg ør egentlige statslige indgreb i arbejdslønnens udvikling. Vi forsøger dermed at pejle os ind på det, som man lidt diffust kunne kalde den socialdemokratiske reformismes lønstyring - uanset om denne så foregår i den ene eller anden politikform.

\section{Indkomstpolitikken som statsligt politikfelt}

Semmler og Hoffmann bestemmer indkomstpolitikken dels udfra en akkumulationsteoretisk bestemmelse af nødvendigheden af at begrænse lønnen, og dels ud fra en generalisering af de historiske specifikke former for indkomstpolitik, der har været fors $\emptyset \mathrm{gt}$ gennemført i forskellige vesteuropæiske lande $\mathrm{i}$ efterkrigstiden som et element i den statslige regulering af $\varnothing$ konomien.

Denne fremgangsmåde giver to sæt problemer. For det første antager $\mathrm{S} / \mathrm{H}$ dermed implicit en automatisk sammenhæng mellem de to synsvinkler: at de teoretiske bestemte akkumulationsn $\varnothing$ dvendige ydre begrænsninger i lønnen også konkret sætter sig igennem som statslig politik i en af de fem nævnte typer, og for det andet antages en generaliseringsmulighed udfra den vesteuropæiske kapitalismes udvikling, som ikke holder for den skandinaviske kapitalismes udvikling og hvis holdbarhed heller ikke begrundes nærmere.

Skal man derfor forsøge at bruge de indsigter som $\mathrm{S} / \mathrm{H}$ 's artikel faktisk bringer, må man gå tilbage til en nærmere undersøgelse af indkomstpolitikkens politikfelt og forsøge en afgrænsning af de mange forskellige former for lønpolitik.

Den første skelnen angår begrebet lønpolitik, som ofte anvendes tvetydigt. Man kan skelne mellem to former for lønpolitik: fagforeningernes og statens.

I første omgang holder vi den fagforeningsmæssige lønpolitik ude. Den statslige politik kan være direkte indgreb i arbejdskontrakten - her er politikfeltet indkomstpolitik - eller det kan være en rammestyring af lønudviklingen her er politikfeltet mere diffust og omfatter alle andre foranstaltninger der påvirker den primære indkomstdannelse, dvs. arbejdsmarkedspolitik, industripo- 
litik osv. Denne opsplitning er til dels sammenfaldende med OECDs opdeling mellem deterministisk og voluntaristisk indkomstpolitik, ${ }^{8}$ men når vi vælger at tage udgangspunkt $\mathrm{i}$ indgrebet i kontrakten og ikke i viljebegrebet, er det for at kunne sammenfatte de politiske/legitimatoriske problemer, som ligger i denne indgrebsform. ${ }^{9}$

De indgrebsformer som $\mathrm{S} / \mathrm{H}$ anfører har alle det direkte indgreb i arbejdskontrakten som gennemsættelsesform, hvad enten det sker som indgreb i kontraktens udformning eller i form af maximalbestemmelser for kontrakten (grænser for lønstigninger med tilhørende statslige sanktionsmuligheder). Hermed overses den anden form for statslig aktion: indgreb i rammerne for kontraktforholdet, enten i form af et egentligt offentligt retligt system for behandling af stridigheder om kontrakten (arbejdsret) eller i form af oprettelse af eller støtte til udformningen af en formel arbejdsmarkedsstruktur (forligsmand, arbejdsmarkedsnævn osv.).

Denne to-deling af de statslige indgrebsformer i arbejdskontrakten gælder for de fleste kapitalistiske lande i Europa (med forskellig udfoldelsesgrad). Analysen af indkomstpolitikkens gennemsættelsesformer må inddrage kombinationen af de statslige politikkers udfoldelsesgrad og fagbevægelsens lønpolitik. Vi vil således vise, at analysen af lønbegrænsningsnødvendigheden i Danmark må lægge særlig vægt på den statslige rammestyring og på fagbevægelsens lønpolitik p.gr.a.denne rammestyrings og

8. Jvf. Socially responsible wagepolicy and inflation, OECD, Paris 1975.

9. Som det vil være fremgået af det foregående hersker der en temmelig uklar begrebsanvendelse i den indkomstpolitiske diskussion. For at have en nogenlunde konsistent terminologi for de forskellige former for lønstyring opererer vi med følgende begreber: 1) indkomstpolitikbegrebet reserverer vi til ydre statslige indgreb i arbejdskontrakten, historiske eksempler fra Danmark er 1963, 1975 og 1977. 2) Statslig rammestyring af betingelserne for arbejdskontrakten indbefatter dels statslige anbefalinger af $1 \varnothing n$ nammer og koordineringsfors $\emptyset \mathrm{g}$ mellem arbejdsmarkedets parter, og dels en arbejdsretlig regulering, som vi nedenfor karakteriserer som konfliktforebyggende og konfliktindkapslende. Der er her en vis glidende overgang til andre politikfelter som arbejdsmarkedspolitik, industripolitik osv. 3) Endelig anvender vi begrebet kooperativ fagforeningspolitik til at karakterisere samspillet mellem fagbevægelse og stat, som det kommer til udtryk i fagbevægelsens lønpolitik. Trods sammenfaldet i terminologi er vi ikke enige med de tyske fagforeningsanalyser, som opererer med begrebet kooperativt (og konfliktorienteret) fagforeningspolitik. Jfr. kritikken i Erling Havn op.cit. p. 17 ff.

Man kunne hævde at de borgerlige økonomer som har beskæftiget sig med indkomstpolitik i deres afgrænsningsfors $\emptyset \mathrm{g}$ er kommet ud over uklarheden ved at definere indkomstpolitik som statslige indgreb i »de primære pengeindkomster« (jvf. f.eks. Leth Jeppesens mange arbejder). Deres totale mangel på forståelse for sammenhængen mellem politikformulering og de grundlæggende samfundsmæssige processer ufortalt, så løser heller ikke denne skarpe afgrænsning problemet om forståelse af den specielle danske lønstyring, men må nøjes med konstateringen om at indkomstpolitikken har været fraværende eller er mislykkedes til trods for at dens effekter tilsyneladende er tilstede i form af en fungerende »velfærds $\varnothing$ konomi $\ll$. 
fagbevægelsens særlige historiske udvikling, dvs. den danske kapitalismes særlige udvikling.

Virkningen af det direkte kontraktindgreb bliver som $\mathrm{S} / \mathrm{H}$ analyserer det og vil fremtræde i de former som de angiver. Det afgørende og kendetegnende er som nævnt, at denne indkomstpolitik er et ydre statsligt indgreb i prisdannelsen, som ellers er et autonomt anliggende for det to parter i arbejdskontrakten - kapital og lønarbejde. Rammestyringen fastholder derimod kontraktautonomien. Kontraktparterne bestemmer selv - fredeligt eller gennem kamp - arbejdskontraktens indhold, og de statslige indgreb tager form af ideologiske opfordringer til at tage samfundsmæssige hensyn eller til opstilling af »samfundsmæssigt forsvarlige rammer« for lønstigningerne, uden hensigt om at gribe ind i det opnåede resultat. Bliver der tale om statslige indgreb, udsprunget af tilsyneladende eller reelle problemer i profitproduktionen, sker det i form af enten almene finanspolitiske midler eller i form af nye rammer for kontraktens funktion (arbejdsretlige regler).

Denne rammestyrings forudsætning og følge er en bestemt type fagforeningspolitik, som både indeholder et element af binding mellem løn, produktivitet og priser, et element af intern tendentiel ophævelse af konkurrencen lønarbejderne imellem og endelig et element af forhåndsaccept af det samfundsmæssige produkts delingsforhold. Gennemsættelsesformen for indkomstpolitik (både det direkte indgreb i dets fem akkumulationsspecifikke typer og rammestyringen eller den indirekte og fagforeningsmæssigt formidlede lønstyring) er betinget af faserne i akkumulationsbevægelsen og samtidig bestemt af klasseforholdets nationale udviklingstrin - altså den politiske kultur og tradition.

I den første fase af akkumulationsudviklingen efter krigen er indkomstpolitikken indholdsmæssigt som nævnt af den type, som hos S/H kaldes type V: arbejdslønnen er residualkategori. Krigen betød en omfattende værdimæssig og stoflig destruktion af kapitalapparatet, og betingelsen for en hurtig akkumulation var naturligvis, at den tilegnede profitmasse muliggjorde en vækst i kapitalapparatet. Samtidig var merværdiraten presset op af selve krigen, og arbejdsløsheden var omfattende. For fagforeningerne betød denne situation, at beskæftigelsen måtte prioriteres over lønkrav, dvs. at arbejdslønnen blev en residualt bestemt størrelse. I de fleste vesteuropæiske lande virkede de $\varnothing$ konomiske forholds stumme tvang således, at de direkte statslige indgreb overfor løndannelsen langt hen ad vejen var helt overflødige. Til gengæld rettede store dele af den statslige generelle $\varnothing$ konomiske politik sig mod forbrugsbegrænsning for at muliggøre en investeringsfor $\varnothing g e l s e$, dvs. for $\varnothing g e t$ profittilegnelse. Den bedst kendte og altid omtalte undtagelse er Holland, hvor gennemsættelsesformen i langt højere grad var statsligt formidlet. Men 
når man drager Holland ind som undtagelseseksempel, må man også trække de særlige forhold frem, der klassemæssigt og ideologisk begrunder den særlige situation. Her tænker vi især på de planøkonomiske forestillinger, som allerede var virksomme i slutningen af trediverne i Holland. Efter krigen blev de udformet som investeringskontrol i en socialdemokratisk-planøkonomisk styring af en række basisindustrier. Forudsætningen for gennemførelsen af denne lønstyring var således planlægning og investeringskontrol, udøvet af komiteer med repræsentanter for fagbevægelse, arbejdsgiverforeninger og staten. Der var således en række andre elementer i tilfældet Holland end blot og bar statslig lønstyring. ${ }^{10}$

I akkumulationsudviklingens anden fase vokser beskæftigelsen. I takt med den voksende beskæftigelsesgrad skifter fagforeningernes prioritering: fra beskæftigelsespolitik til lønpolitik. Der rejses og gennemføres langt mere aktive lønkrav. Resultatet bliver umiddelbart en voksende lønkvote. Indkomstpolitikken bliver en reaktion på den inflation, som ledsager den høje beskæftigelsesgrad. Typerne er ifølge Semmler/Hoffmanns afgrænsning IIIV, dvs. en principiel lønstyring. Gennemsættelsesformerne har historisk været forskellige, men det karakteristiske èr dog, at der ikke er tale om ydre statslige indgreb i denne fase. Den konkrete udformning har selvfølgelig en række specielle nationale nuancer, der er betinget af f.eks. betalingsbalanceforhold, fagbevægelsens styrke og sammensætning samt de politiske styringsforhold generelt. Disse nationale forskelle bestemmer udformningen af de indirekte styringsmidler, som i den statslige reguleringspolitik skal supplere fagbevægelens lønpolitik.

I akkumulationsudviklingens tredje fase, som er den begyndende stagflation, bliver indkomstpolitikken stadigt mere deterministisk. Lønstop (type I) optræder stadigt hyppigere, og tilsyneladende hyppigst i lande hvor den aktivt kæmpende del af arbejderklassen har stor indflydelse i fagbevægelsen (England, Italien, Frankrig). Hvor der ikke er en stærk, kæmpende arbejderklasse (BRD) eller hvor det socialdemokratiske hegemoni fortsat er stærkt (Skandinavien), sker der ingen ændring i lønstyringens former.

I akkumulationsudviklingens fjerde fase slår stagflationstendenserne ud i åben verdensmarkedskrise. For de svageste nationalstater på verdensmarkedet bliver egentlige statslige indkomstpolitiske indgreb meget hurtigt nødvendige. Samtidig skifter både forsøgene på at gennemføre og de gennemførte forslag til indkomstpolitik også type. Lønstop er ikke længere tilstrækkeligt til at sikre høje profitmarginaler. Kun residualberegningen af arbejdslønnen synes at kunne sikre en tilstrækkelig tilegnet profit. Danmark er som den svageste nationalstat i Skandinavien først blevet ramt af ver-

10. se også Erling Havn op.cit. p. 46 ff. 
densmarkedskrisen og har også først set kravet om indkomstpolitik i denne utilslørede form. Ganske vist holder de første indgreb sig til form I, men det politiske krav og de $\varnothing$ konomiske vismandsråd bag politikformuleringen går mod form $\mathrm{V}^{11}$

I takt med krisens uddybning vil indkomstpolitikkens former ændres (og indholdet naturligvis blive endnu mere utåleligt) - med mindre krisens selvstændige disciplinerende virkninger betyder en så kraftig reduktion af fagbevægelsens lønkrav - jvf. f.eks. den allerede fremkomne accept af det næste indgreb i 1979 - at form I kan bibeholdes og SD langsomt kan vende tilbage til en eller anden form for rammestyring og kooperativ lønstyringspolitik.

Skal vi bevæge os over denne meget generelle akkumulationsafhængige typologi og over de indledende forsøg på at afgrænse indkomstpolitikfeltet og bestemme den statslige lønpolitiks former, så er det nødvendigt at undersøge i hvilken grad disse former og deres udvikling er betinget af særlige $\varnothing$ konomiske forhold, og i hvilken grad de er fremkaldt af særlige samfundsmæssige forudsætninger - altså de strukturelle forhold omkring løndannelse, fagforeningsstruktur, arbejdsmarked osv., som udgør en væsentlig del af betingelserne for det socialdemokratiske hegemoni i dansk arbejderbevægelse.

Der er altså to sammenhængende problemer forbundet med undersøgelsen af den indkomstpolitiske udvikling:

1. dens særlige akkumulationsmæssige forudsætninger, og

2. dens særlige politiske forudsætninger.

Disse forhold skal vi med udgangspunkt i den danske udvikling behandle i de efterfølgende afsnit. Først skal vi se på akkumulationsbetingelserne og akkumulationsprocessens udvikling i efterkrigstiden og derefter på arbejdsmarkedsstrukturen i bred forstand, herunder også den konkrete retlige udformning af forholdet mellem lønarbejde og kapital.

\section{De akkumulationsmassige betingelser for den økonomiske politik i efterkrigstiden}

Et af de centrale træk i den nationale akkumulationsproces er, at der er tale om en »afhængig « kapitalakkumulation, dvs. at dens betingelser i vid udstrækning

11. Jvf. DØR, november 1976, hvor betragtninger over profittens nødvendige forøgelse for første gang i rådets historie er afgørende for politikrådgivningen. 
bestemmes af den internationale kapitalismes akkumulationsniveau og -betingelser. Det er således i høj grad verdensmarkedsudviklingen, der bestemmer om der er opgangstider eller krise i Danmark.

Det er karakteristisk for den afhængige kapitalakkumulation,

1. at det nationale marked er begrænset. Det betyder - så længe kapitalens akkumulationsbevægelse foregår i nationale former - at der ikke udgår så kraftige selvstændige impulser fra det beskedne nationale marked, at dette er i stand til effektivt at kompensere for verdensmarkedets udviklingstendenser. $^{12}$

2. at kapitalkoncentrationen er uudviklet: Der produceres stadig i mange små produktionsenheder med ringe kapitalapparat og et lille antal beskæftigede arbejdere. Ligeledes er kapitalcentraliseringen meget beskeden: Monopoliseringsprocessen er faktisk snarere regressiv. Fra 1960 til 1970 vokser således den andel af den samlede omsætning som produceres i små og mellemstore virksomheder (10-499 ansatte) på bekostning af de stores andel (mere end 500 ansatte).

3. at den industrielle udvikling historisk indtil tressernes begyndelse var bundet til landbruget. Først i begyndelsen af 1960'erne blev industriproduktionen, såvel målt som andel af BFI som målt i forhold til eksporten større end landbrugsproduktionen.

4. at den danske industri i meget ringe grad er integreret i kapitalens internationaliseringstendenser. Danske investeringer i udlandet er meget beskedne, og de udenlandske investeringer i den danske industri var i tresserne under 3\% af de samlede årlige investeringer. Andelen af udenlandsk ejede virksomheder i Danmark var i $19718 \%$ af totalomsætningen.

Denne afhængige udvikling kommer til udtryk i flere forskellige forhold. De to mest bemærkelsesværdige er dels den særlige udvikling i kapitalintensitet, arbejdsproduktivitet og kapitalrentabilitet især efter 1967, og dels at krisen og kapitalens krisecyklus - herunder krisecyklens varighed - tilsyneladende bestemmes af andre nationale kapitalers udviklingsbetingelser, især udviklingen i BRD.

I den historiske udvikling i efterkrigstiden kan man skelne mellem forskellige faser i akkumulationsprocessen: Den umiddelbare efterkrigssituation, 1950'ernes stagnative vækstperiode, 1960'ernes kraftige og omfatttende vækst

12. Dette gælder for totalkapitalen. For de virksomheder, som både producerer til hjemmemarked og til eksport, vil der naturligvis være kompensationsmuligheder. Det er kendetegnende for disse kapitaler at de ikke kun mht. realisering af merværdien, men også delvis mht. produktion af merværdi er verdensmarkedsorienterede. De udvikler sig stadig mere til egentlige multinationale koncerner. Denne tendens gælder således for de 39 industrivirksomheder som i år 1972 var ansvarlig for 55\% af den danske industrieksport. Jvf. Jens Guldager, Monopolkapital i Danmark, Kbh. 1978 s. 73. 
og 1970'erne med en stadig mere skærpet kriseagtig udvikling. I sammentrængt form kan man sige om situationen efter 2. Verdenskrig: $:^{13}$ at den danske industri i løbet af besættelsestiden var blevet mere arbejdsintensiv, at produktionsapparatet i det væsentlige havde samme produktionskapacitet som i 1938, at udbytningsbetingelserne var blevet forbedret, at akkumulationen stort set kun var monetær - dvs. en ophobet akkumulationsfond i monetære størrelser, som ikke modsvarede en real akkumulation. Dette må i første række tilskrives afhængigheden af verdensmarkedet, hvor manglende råvarer, manglende internationale betalingsmidler og verdensmarkedsk øbekraft, satte de vigtigste skranker, som hindrede den monetære akkumulation i at blive en real akkumulation.

Politisk var den danske arbejderklasse for første gang i sin historie virkelig splittet i og med den voldsomme opbakning bag DKP. Uden at ville gå ind i en diskussion omkring DKPs strategiske og taktiske linie i denne periode og her søge »«årsagen« til DKPs hurtige tilbagefald til minoritetspositionen fra trediverne, er det i vor sammenhæng vigtigt at understrege: DKP var i relation til den $\varnothing$ konomiske politik og den $\varnothing$ konomiske teori ikke til at skelne fra venstre-kenyesianske socialdemokrater, som på dette tidspunkt havde kronede dage i partiet. Den $\varnothing$ konomisk-politiske debat og modsætningerne i arbejderbevægelsen måtte derfor først og fremmest foregå omkring de udenrigspolitiske aspekter af $\varnothing$ konomien.

Rekonstruktionen af den danske kapitalisme blev efter befrielsessommeren overladt til socialdemokratiet. Det socialdemokratiske hegemoni blev genoprettet allerede i 1945/46 på trods af den tilsyneladende store opbakning om DKP. Men hvad ville socialdemokraterne?

Trediverne var for socialdemokraterne en overgangsfase i kapitalismens udvikling, hvor planøkonomiens nødvendighed blev tydelig. Efter krigens afslutning skulle man således anvende 30'ernes kriseerfaringer i et genopbygningsprogram, hvis hensigt det var »at genvinde førkrigstidens levestandard, forbedre den og skabe fuld beskæftigelse med større social lighed $\ll .{ }^{14}$

Den økonomiske politiks mål skal nås gennem en successiv vækst i den statsligt styrede del af produktionen, hvor styringsinstrumenterne angiveligt dels er investeringskontrol og dels arbejdsmarkedskontrol. Begrundelsen for denne linie var angivelig at den danske kapitalisme ikke var moden til en nationalisering, hvorfor f.eks. den engelske nationaliseringsmodel ikke kunne anvendes her. Forudsætningen for denne stadige udvidelse af investerings- og arbejdsmarkedskontrollen er imidlertid, at den ventede opsvingsperiode efter

13. til udbygning af dette se Kapitalakkumulationen efter 1940 II, Kbh. 1975 p. 99.ff.

14. Økonomisk oversigt 1947 og 1948? Arbejderbevægelsens Erhvervsråd, Kbh. 1949 p. 5. 
krigen kan fastholdes. Og på dette punkt bryder de socialdemokratiske visioner realt sammen omkring 1948, hvor det krigsbetingede opsving rinder ud og arbejdsløsheden igen begynder at vokse.

Men umiddelbart efter krigen var planøkonomi samlebegrebet for den socialdemokratiske opfattelse af kapitalismens udvikling. Efter 1948 ændredes den $\varnothing$ konomiske situation og efterhånden ændredes opfattelsen af kapitalismen og den reformkapitalistiske strategi: Keynesianismen træder i stedet for de planøkonomiske forestillinger.

Problemet var imidlertid, at det p.g.a. den danske kapitalismes store verdensmarkedsafhængighed var vanskeligt at udnytte de keynesianske virkemidler fuldt ud. Den kortsigtede opgave blev derfor indenfor den ramme, som var sat af den af landbruget skabte valutamængde, at skabe en vækstpolitik, hvis mål var fuld beskæftigelse, stigende vækst og hurtigere industriel udvikling. Men rammen var for lille, og det $\varnothing$ konomisk politiske dilemma i 1950 'erne var hele tiden betalingsbalancen overfor arbejdsløshedstallene.

Halvtredserne var en stagnationsperiode, hvor arbejdsløsheden hele året lå på mellem 5-8\% af arbejdsstyrken. Antallet af ydede arbejdstimer i industrien var stort set konstant, hvilket også gælder for industriens investeringsrate, der årligt lå på $7-10 \%$ af BFI. Den beskedne realakkumulation, som finder sted, baserer sig overvejende på det levende arbejde som vækstfaktor. Forudsætningerne for dette var: Akkumulationsbetingelserne var forbedret gennem besættelsestiden, arbejdsløsheden var stor nok til at skabe en tilstrækkelig reservearme, og den bestandige afvandring fra landbruget forøgede udbuddet af ubeskæftiget arbejdskraft. Det begrænsede nationale marked udelukker tilsyneladende en hurtig og stabil kapitalakkumulation på rent nationalstatsligt grundlag. Først i og med verdensmarkedsopsvinget efter den internationale recession i 1958-59, sker der en bedring af bytteforholdet, og dette sammen med den stærkt udvidede efterspørgsel på verdensmarkedet muliggør en høj akkumulationsrate for den danske kapital. Efter 1958 vokser investeringsraten meget hurtigt; ledigheden falder i løbet af to år og tressernes fuldbeskæftigelses situation begynder.

Den fulde beskæftigelse medfører, at fagbevægelsen ved overenskomstforhandlingerne presser på for forbedring af arbejdsforhold og arbejdstidsforkortelse, hvilket resulterer i et fald i det ydede antal arbejdstimer i industrien efter 1965. Den begyndende rationalisering i industrien betyder samtidig en ganske vist endnu temmelig svag strukturel udstødning/frisættelse af arbejdskraft som følge af kapitalens stigende organiske sammensætning. Denne ledighed kommer kun frem i ledighedstallene i enkelte nedgangsår - f.eks. 1968, hvor BRD overvinder krisen ved eksportfremstød, der omvendt betyder, at Danmark importerer den tyske krise. Den overvejende tendens er imidlertid at 
frisættelsen af arbejdskraft $\mathrm{i}$ industrien opsuges af andre sektorer især den offentlige sektor.

Dette betyder, at den fulde beskæftigelse kun kan opretholdes ved en stadig udvidelse af den uproduktive anvendelse af arbejdskræfter, hvilket samfundsmæssigt skal financieres af den merværdi/profit, som skabes af den produktive arbejdskraft.

Ved at se på udviklingen i kapitalrentabiliteten og dens elementer, kan vi få et sammenfattende billede af den danske kapitals akkumulationsproces.

\section{Tabel 1}

Procentuel vækst i arbejdsproduktivitet $(\mathrm{Y} / \mathrm{L})$ og kapitalintensitet $(\mathrm{K} / \mathrm{L})$ og udviklingen i lønkvote (W) og kapitalrentabilitet (pi)

\begin{tabular}{|c|c|c|r|r|r|r|r|r|}
\hline & \multicolumn{2}{|c|}{$\begin{array}{c}\text { Arbejdsproduk- } \\
\text { tivitet }\end{array}$} & \multicolumn{2}{|c|}{$\begin{array}{c}\text { Kapital- } \\
\text { intensitet }\end{array}$} & \multicolumn{2}{|c|}{ Lønkvote } & \multicolumn{2}{|c|}{$\begin{array}{c}\text { Kapital- } \\
\text { rentabilitet }\end{array}$} \\
\cline { 2 - 8 } & total & $\begin{array}{c}\text { genn. } \\
\text { sn. }\end{array}$ & total & $\begin{array}{c}\text { genn. } \\
\text { sn. }\end{array}$ & $\begin{array}{c}\text { udv. } \\
\text { tend. }\end{array}$ & niveau & $\begin{array}{c}\text { udv. } \\
\text { tend. }\end{array}$ & niveau \\
\hline $1951-56$ & 14,8 & 2.5 & 33.2 & 5.5 & + & 0.605 & - & 0.997 \\
$1956-59$ & 14.4 & 3.6 & 16.0 & 4.0 & - & 0.605 & + & 0.941 \\
$1959-67$ & 56.9 & 6.3 & 101.4 & 11.3 & + & 0.619 & - & 0.778 \\
$1967-73$ & 61.5 & 8.8 & 35.2 & 5.0 & 0 & 0.654 & + & 0.722 \\
$1973-76$ & 17.0 & 4.3 & 15.9 & 4.0 & $+/ 0$ & 0.690 & - & 0.694 \\
\hline
\end{tabular}

+ betyder stigende tendens; - betyder faldende tendens; 0 betyder stagnerende tendens Kilde og beregningsmetode se bilaget s. $51 \mathrm{ff}$.

For hele perioden fra 1951 og frem gælder det, at der er tale om et konstant faldende niveau for kapitalrentabiliteten. Bag dette gemmer der sig imidlertid en cyklisk udvikling, hvor den forskellige udvikling i kapitalrentabilitetens elementer betinger en periodisk forskelligartet akkumulationsudvikling.

Det generelle udviklingsmønster for 50'erne og 60'erne er det samme, selv om udviklingsniveauet er meget forskelligt. Begge årtier indledes med en fase, som er kendetegnet af en kraftig vækst i kapitalintensiteten i forhold til udviklingen i arbejdsproduktiviteten. 
I begge disse perioder, 1951-56 og 1959-67, drives de strukturelle ændringer i produktionsprocessen frem af en relativ stor stigning i investeringerne. Kendetegnende for denne akkumulationsfase er, at der finder stærke teknologiske fornyelser, dvs. primære innovationer, sted. Denne innovative vækst i kapitalapparatet resulterer i en stigende teknisk og organisk sammensætning af kapitalen og dermed en faldende kapitalrentabilitet.

Fra 1956-59 er der derimod en voksende tendens i kapitalrentabiliteten. Det sker først og fremmest, fordi lønkvoten falder, hvilket igen skyldes de specielle arbejdsmarkedsforhold i årene 1956 og 1958. Samtidig med faldet i lønkvoten mindskes væksten i kapitalintensiteten i forhold til perioden før. Det tyder på, at der er tale om en anden form for vækst, en vækst, hvor de sekundære innovationer er fremherskende. Det drejer sig om ændringer i arbejdskraftens kvalifikationer, arbejdsorganisering, lønsystemer og lønformer - med andre ord produktionsprocessens subjektive aspekter. Det er generelt ændringer, som muliggør forøget produktivitet, som igen netop foreligger som mulighed i kraft af den allerede gennemførte teknologiske ændring.

Dette udviklingsmønster bliver helt tydeligt i perioden efter 1967, hvor der på baggrund af en meget voldsom forøgelse af arbejdsproduktiviteten og en voksende profitmasse kan iagttages en stigende tendens i kapitalrentabiliteten og dermed en almen profitabilitetsforbedring. Det kan ikke undre, at produktiviteten pr. beskæftiget arbejder i tressernes slutning (1967-73) vokser hurtigere end ved periodens begyndelse. Det samme er tilfældet i de fleste europæiske lande. Men i disse sker det med baggrund i en tiltagende kapitalintensitet. Hermed falder kapitalrentabiliteten - jvf. udviklingen i BRD. ${ }^{15}$ Udviklingen i Danmark er på dette punkt helt anderledes: væksten i arbejdsproduktiviteten er langt kraftigere end den samtidige forøgelse af kapitalintensiteten. Vi kan således fastslå, at det er et specielt træk ved den danske udvikling, at fasen med sekundærinnovationer, hvis resultat er for$\emptyset$ get arbejdsproduktivitet og -intensitet, dominerer akkumulationsudviklingen i denne periode.

En af de væsentligste forudsætninger herfor, er det særlige forhold mellem fagbevægelsen og Socialdemokratiet i den historiske sammenhæng. Dette skal vi senere tage op for at kunne belyse, hvordan denne udvikling har været mulig.

Et andet særligt træk ved den danske udvikling er, at en egentlig industriel cyklus først udvikler sig gradvist og får samme forløb og samme varighed som den vesttyske kapitals cyklus. Dette gælder krisecyklen fra 1967/68 til 1973/74. I disse år udvikler krisecyklen sig i Vesttyskland som en 7-8

15. Jvf. Altvater m.fl. i Kurasje 12 og 13. 
årig cyklus med en »mellemkrise«. Fra krisen i 1966/67 over opsvinget i 1968/69, mellemkrisen i 1971/72 og det midlertidige opsving i 1973 til krisen i $1974 / 75 .{ }^{16}$

Danmark »importerer « 1966/67-krisen fra BRD med et års forsinkelse. Herefter følger opsvinget i 1969, kontraktionen i 1970, mellemkrise i 1971/72, midlertidigt opsving i 1972/73 og en meget stærk krise i løbet af 1974. Cykluslængden er den som den tyske omkring 7 år, og forløbet det samme. ${ }^{16 \mathrm{~b}}$ Med dannelsen af denne identiske cyklus for den tyske og danske kapital kan det antages, at mulighederne for fremtidige afvigende forløb i den danske $\varnothing$ konomiske udvikling er blevet yderligere forringet. Man kan derfor tale om to forskellige sæt af betingelser for den danske kapitalistiske udvikling: De betingelser der var tilstede før og efter 1974. Op til 1974 sætter en synkronisering af krisecyklen med den vesttyske cyklus sig igennem, hvilket uddyber den danske verdensmarkedsafhængighed.

Perioden op til 1974 var samtidig den periode, hvor den socialdemokratiske reformkapitalisme og rammestyringen af økonomien kunne fungere.

Med krisegennemslaget, den stærkt stigende arbejdsløshed og de faldende investeringer, sker der en brat vending i akkumulationsmønstret. Fra 1973-76 halveres væksten i arbejdsproduktiviteten i forhold til den foregående periode, og væksten i kapitalintensiteten falder til niveauet før det kraftige akkumulationsopsving efter 1959. Samtidig bevæger lønkvoten sig - på trods af at den for perioden som helhed kun udviser en meget svag stigende tendens - op på et højere gennemsnitsniveau, hvilket medfører såvel en faldende tendens i kapitalrentabiliteten som et lavere niveau. Med den stærke verdensmarkedssammenhæng, den synkrone internationale krise og den skærpede verdensmarkedskonkurrence kan impulserne til et akkumulationsopsving kun udnyttes på baggrund af forbedrede nationale udbytnings- og profitproduktionsbetingelser, altså gennem samtidig vækst i arbejdsproduktiviteten og fald i lønkvoten og lønomkostningerne.

Men hermed er der også sat helt nye betingelser for den socialdemokratiske reformkapitalismes og stabiliseringspolitiks funktionsmåde.

16a. Jvf. herom Semmler og Hoffmanns artikel i dette nummer af Kurasje, p. $55 \mathrm{ff}$.

16b. Jvf. bilagstabellen samt OECD, Economic Surveys Denmark, july 1975 p. 31-32. 


\section{De politiske forudsætninger for den danske indkomstpolitik}

Udover diskussionen om de $\varnothing$ konomiske/akkumulationsmæssige betingelser og baggrund for indkomstpolitikkens nødvendige og mulige gennemsættelse har den indkomstpolitiske debat fokuseret på de politiske forudsætninger for og konsekvenser af indkomstpolitikken. Og dette i særlig grad i den borgerlige diskussion, hvor den konkrete organisering af arbejdsmarkedet, forholdet mellem fagbevægelse og stat og de legitimitetsmæssige problemer i forbindelse med indkomstpolitikkens forskellige gennemsættelsesformer har spillet en afgørende rolle. ${ }^{17}$

De generelle konklusioner, der er draget i denne debat, kan kort opsummeres således: De nødvendige/optimale politiske forudsætninger for en virkningsfuld gennemsættelse og fastholdelse af indkomstpolitikken er

a) et gennemorganiseret, autonomt arbejdsmarked med en udstrakt grad af retlig regulering af forholdet mellem arbejdsmarkedets parter - dvs. retlig regulering af lønarbejde-kapitalforholdet;

b) en kooperativ fagforeningspolitik vis a vis staten, hvor denne socialstatslige, »demokratiske model « for samarbejde mellem den reformistiske fagbevægelse og staten har som væsentlige karakteristika, at fagbevægelsen gennem integration i det politiske system og deltagelse i statslige og quasistatslige organer $\emptyset$ ver sin indflydelse på den statslige politik, men samtidig underlægges en »samfundsmæssig ansvarlighed «, således at den også i de autonome lønforhandlinger agerer udfra en »samfundsmæssig ansvarlig lønpolitik«; samt

c) den almene historiske erfaring, at indkomstpolitikkens succes er afhængig af, i hvilken udstrækning de dominerende politiske kræfter i statsapparatet fungerer som protagonister overfor fagbevægelsens politiske interesser.

Når disse tre forhold er opfyldt, vil rammestyringen og den kooperative lønstyring kunne fungere med høj effektivitet. Det samme gælder også for den statslige indkomstpolitik. Her kan man ydermere sige, at graden af legitimitetsproblemer for den borgerlige stat, der følger af den direkte statslige inter-

17. Jvf. Braun op. cit. L. Ulmann, R.J.Flanagan, Wage Restraint, A study of incomepolicies in Western Europe, Berkeley 1971, samt diverse OECD-rapporter. Den kraftige focusering på fagbevægelsens rolle viser i øvrigt tydeligere end mange lange analyser, at det i hvert fald er de borgerlige $\varnothing$ konomer og politikmagere pinligt bevidst, at det centrale element $\mathrm{i}$ indkomstpolitikken er lonbegransning - uanset hvilke yderligere foranstaltninger en konkret indkomstpolitik måtte være garneret med. 
vention i løndannelsen, er afgørende bestemt af, at den »demokratiske model« for samarbejde mellem fagbevægelse og stat ikke bryder sammen. Ikke uden grund er de skandinaviske lande blevet fremhævet som prototypen på et sådant politisk system. Vi skal i det følgende nærmere gennemgå udviklingen af disse forudsætninger for Danmarks vedkommende, idet vi skal vise, at de sammen med den såkaldte solidariske lønpolitik udgør det samfundsmæssige grundlag for den form for indkomstpolitik, der har været kendetegnende for efterkrigstiden.

\section{a) Retliggørelsen af klassekampen}

Et afgørende kendetegn for den danske arbejdsmarkedsstruktur er den meget tidlige og høje organisationsgrad og den samtidige retliggørelse af lønarbejdekapitalforholdet. Med dannelsen af DSF og DA i slutningen af forrige århundrede og med indgåelsen af septemberforliget i 1899, var den danske klassekamp allerede samtidig med en egentlig industrikapitalismes spæde start, lagt ind i rammer, som mange steder i Europa idag forsøges indført som landvindinger for ro og orden på arbejdsmarkedet.

Den aftale, som blev sluttet mellem de to centrale organisationer, omfattede alle generelle spørgsmål dvs. arbejdstid, arbejdsbetingelser, ferieforhold og de generelle lønstigninger til alle arbejdere. Derudover blev der efterhånden gennem de første årtier af dette århundrede institutionaliseret et forhandlingssystem for de særlige spørgsmål, som måtte eksistere indenfor de forskellige områder, dvs. stykløns- og bonusaftaler og specielle lønsystemer for de enkelte brancher.

I 1910 oprettedes ved lov Den permanente Voldgiftsdomstol, som en endelig kodificering af dels årtiers krav fra fagbevægelsen om faste voldgiftsinstitutioner til afgørelse af stridigheder og dels den retspraksis, som havde udviklet sig omkring tolkningen og gennemtvingelsen af septemberforligets bestemmelser. »Arbejdsretten « blev således oprettet ved statsligt initiativ, men det er vigtigt at fastholde, at grundlaget for dens oprettelse og funktionsområde var forhandlinger og aftaler mellem parterne, udtrykt i den sk. Norm for behandling af faglig Strid og selve betænkningsarbejdet, der lå til grund for loven.

Men ikke alene det arbejdsretlige system og dets funktionsområde er blevet til ved selvstændig aktion fra arbejdsmarkedets parter, også den retlige regulering i detailler, dvs. sanktionsmuligheder og procedurer for rettens arbejde, ja selv 
udøvelsen af den dømmende funktion er en integreret del af de to parters arbejde.

Et af de mest afgørende træk ved retliggørelsen af klassekampen - som jo i nogle andre lande blot består $i$ at en politimæssig myndighed bliver sat til at håndhæve overholdelsen af bestemte regler - er institutionaliseringen af dele af lønkampen og dermed illegalisering af andre gennem opdelingen af konflikterne i rets- og interessekonflikter, som det skete ved Den permanente Voldgiftsrets nedsættelse i 1910. Retskonflikter drejer sig om fortolkningen af overenskomster og aftaler og brud på sådanne. Disse konflikter må ikke imødegås med kollektive kampskridt, men skal på forskellige måde behandles i det arbejdsretlige system. For at fastholde og understrege Retskarakteren ved denne slags konflikter har man indført dels en række procedureregler fra de almindelige domstole, dels højesteretsdommere som dommere, dels et bodssystem, som ganske vist ikke udmåles efter almindelige erstatningsretlige principper, men hvor boden er exigibel dvs. kan inddrives af det offentlige.

Retskonfliktbegrebet sikrer, at de centralt indgåede overenskomster kan overholdes, uanset hvordan arbejderklassens styrke og leveforhold udvikler sig i overenskomstperioden. Samtidig understøtter begrebet forestillingen om arbejdskontrakten eller overenskomsten som en tendentielt »retfærdig « fordeling af produktionsresultatet,. Når den centrale overenskomstforhandling er overstået, er der i princippet ikke længere en interessekonflikt eller modstående interesser mellem arbejder og kapital - kun fortolkningstvivl.

Begrebet interessekonflikt er derimod reserveret til områder, som ikke er dækket af kontrakten eller for hvilke kontrakten er udløbet. For denne type konflikter er der ingen retslig instans, men kun en række forhandlingsregler og mæglingsinstanser, som skal forhindre konflikten i at bryde ud i åben kamp.

Løses konflikten ikke her, er der mulighed for »kollektive kampskridt«. Dette er af særlig betydning for minimallønsområdet, som omfatter ca. halvdelen af industriarbejderne. Indenfor dette lønsystem er det kun grundsatserne der aftales ved de generelle overenskomster, mens akkordtillæg, bonus m.v. er genstand for lokale løbende forhandlinger. Her er der altså indenfor visse grænser mulighed for »lovlige « løn- og arbejdsforholdsaktioner. Vi skal senere vende tilbage til den lønmæssige konsekvens af dette system. Ved forhandlingen omkring den nye generelle overenskomst, som sker fælles for næsten alle arbejdere, og som jo principielt drejer sig om en interessekonflikt, da den gamle »kontrakt« er udløbet, er der opstillet en lang række procedureregler og tidsfrister, som skal forhindre konflikten i at bryde ud. Og endelig er der ud 
over »Arbejdsretten « oprettet en forligsmandsinstitution, som - formelt uafhængigt af staten - skal gribe ind i forhandlingerne og forsøge at forhindre truende konflikter.

Forligsmandslovens udvikling er et godt eksempel på det arbejdsretslige systems udvikling. Hver gang der igennem årene er blevet lavet ændringer, har sigtet været en udvidelse af institutionens konfliktbegrænsende muligheder. I tæt samarbejde med fagbevægelsen er der løbende blevet udformet regler, som muliggjorde enten generelt en svækkelse af de kollektive kampskridts effekt eller specifikt en svækkelse af militante dele af fagbevægelsen - f.eks. gennem sammenkædningsreglernes mulighed for at ophæve et »nej« ved afstemningerne ved sammenkædning med områder med stort ja-flertal.

Det er vigtigt at bemærke, at efter denne juridiske klassifikation af klassekampen, er langt de fleste konflikter lagt ind under retskonfliktbegrebet, hvor der hersker fredspligt, dvs. forbud mod aktion, og hvor afgørelsen træffes af de centrale organisationer og arbejdsretten og hvor konflikten er løftet væk fra de enkelte fagforeninger og arbejdspladser.

Mens denne struktur i hovedtrækkene var etableret allerede før første Verdenskrig, så udbygges og forfines den løbende i mellemkrigstiden og her især under og umiddelbart efter verdenskrisen 1930-32. Tendensen i udviklingen på lønarbejdersiden er en centralisering af magten i Landsorganisationen (LO) og dermed en inddæmning af fagoppositionelle og militante fagforeningers mulighed for at føre en mere offensiv kamp mod kapitalen. Fra midten af tyverne og specielt i trediverne, hvor Socialdemokratiet er blevet det statsbærende parti, sker der yderligere en tendentiel statsliggørelse af overenskomstforhandlingerne. Godt nok fastholdes tarifautonomien formelt, men i hvert enkelt tilfælde, hvor det autonome system ikke formår at løse modsætningerne og en konflikt derfor bryder ud eller truer med at bryde ud, griber regeringen ind og ophøjer mæglingsforslaget til lov. Dernæst udformes under arbejdsmarkedsparternes medvirken en lovgivning, der gennem udvidelse af forligsmandens beføjelser, ændringer i mæglingssystem og afstemningsregler m.v. skal foregribe gentagelsen af den slags konflikter, som netop var overstået. ${ }^{18}$

18. Også i perioden efter Den anden Verdenskrig sker der flere indgreb i overenskomstafslutningen i form af ophøjelser af mæglingsforslag til lov, men i modsætning til 30'erne sker der kun få væsentlige ændringer i det fagretlige system i forbindelse hermed. »Modellen« fungerer dog stadigvæk. Således dker der som følge af konflikten i 1956 en ændring af forhandlingsreglerne, der skal sikre mod gentagelser.

En Enkelt anden ændring skal dog nævnes som eksempel på den sensibilitet som såvel arbejdsmarkedets parter som staten udviser overfor det fagretslige systems funktionsduelighed 
Det vigtige i denne intervention fra statens side er således i vores sammenhæng ikke de enkelte indgreb i lønfastsættelsen. Der var i sigtet med disse indgreb ikke tale om egentlig fors $\varnothing \mathrm{g}$ på statslig begrænsning af lønudviklingen - dette skete gennem krisens stumme tvang ${ }^{19}$ - men om konfliktindkapsling.

Det afgørende er den udbygning og stabilisering af det arbejdsretlige reguleringsnet, der sker opfølgende og som sigter mod en udbygning af de samfundsmæssige strukturer og institutioner, der muliggør fastholdelsen af arbejdsmarkedets autonomi, men samtidig medfører en institutionalisering af klassekampen.

\section{b) Forholdet mellem fagbevægelse og stat}

Parallelt med den skitserede udvikling i den retlige regulering af lønarbejderkapitalforholdet og den deraf følgende institutionalisering af klassekampen, udvikles også grundlaget for en ændring af forholdet mellem fagbevægelse og stat henimod en kooperativ, »demokratisk « samarbejdsmodel. ${ }^{20}$

Vi skal ikke her gå ind i en konkret, historisk analyse af denne udvikling, men kort fastholde nogle afgørende elementer til forståelsen af ændringen af forholdet mellem fagbevægelse og stat; forhold som samtidig er afgørende for videreførslen af denne politik i efterkrigstiden.

Krisen i trediverne betyder en kraftig forringelse af arbejderklassens samfundsmæssige situation. Den hastigt voksende reservearmé betyder tendentielt en partikularisering af arbejderklassen og en voksende konkurrence arbejderne imellem, samtidig med at der ikke blot sker en vending i reallønsudviklingen, men i de første kriseår endog et (kraftigt) fald for de, der stadig er beskæftiget.

Kapitalens almene tendens, at $\varnothing$ ge profitabiliteten gennem at presse prisen på varen arbejdskraft har i denne situation særdeles gunstige historiske

og legitimitet. I forbindelse med det stærkt stigende antal vilde strejker i slutningen af 60 'erne og begynelsen af 70'erne og det dermed voksende antal sager i Arbejdsretten, vokser modstanden mod Arbejdsretten ikke blot i den militante del af fagbevægelsen men også langt ind i de socialdemokratiske rækker. Som en konsekvens heraf revideres Arbejdsretsloven i 1973, således at spontane arbejdsnedlæggelser, hvor arbejdet genoptages indenfor 48 timer ikke indklages for Arbejdsretten.

19. Således falder realtimelønnen $(1914=100)$ fra index 170 i 1931 , hvor krisen begynder sit gennemslag i Danmark til 151 i 1937 og 157 i 1939 jvf. Erling Olsen, Danmarks økonomiske historie siden 1750, Kbh. 1962, p. 212 f.

20. Således gennemføres en stor del af statens kriseregulerende politik gennem etablering af quasistatslige organer med deltagelse af diverse interesseorganisationer, herunder fagbevægelsen, eller gennem inddragelse af disse i udformningen af reguleringspolitikken i et omfang, der hidtil kun var kendt fra arbejdsmarkedspolitikken. 
udfoldelsesbetingelser, hvilket giver sig udslag i en meget aggressiv lønnedskæringspolitik fra arbejdsgivernes side. Denne udvikling udgør en alvorlig trussel mod fagforeningernes mulighed for at varetage deres funktionsimperativ: gennem ophævelsen af konkurrencen mellem arbejderne at gennemsætte klassens interesser overfor kapitalen. ${ }^{21}$

Tendentielt vil dette føre til nedbrydning af den materielle basis for fagforeningsorganiseringen dvs. skærpe konkurrencen mellem arbejderne, hvilket vil give sig udtryk i en legitimitetskrise for fagbevægelsen. I Redaktionskollektiv Gewerkschaftens (R.G.) fors $\varnothing \mathrm{g}$ på en almen bestemmelse af den fagforeningsmæssige organisation og reformisme skitseres denne tendens således, »at arbejderne i faser, hvor kapitalens akkumulationsevne aftager, nødvendigvis i første omgang vil begribe forringelsen henholdsvis begrænsningen af forbedringen af deres livbetingelser som resultat af deres fagforeningsmæssige organisations mangler og fejl, eller også af deres politiske repræsentations (f.eks. Socialdemokratiet) forkerte politik. For går de ud fra at deres sammenslutning er betingelsen for den varige forbedring af deres eksistens overfor kapitalen, så må en forringelse også i første omgang føres tilbage til deres sammenslutnings former ${ }^{22}{ }^{22}$

Selv om vi er enige $i$ at krisen fremkalder en latent trussel mod fagforeningernes legitimitet, så mener vi, at R.G. forkorter problemstillingen ved at undlade at bestemme denne udvikling i sin modsætningsfyldthed. Dvs. at forringelsen af levevilkårene øger behovet for »konkurrencebegrænsning «, og at kapitalens tryk udstiller den fagforeningsmæssige sammenslutnings magtesløshed og dens absolutte nødvendighed, især i situationer hvor politiske og faglige alternativer historisk har været fraværende.

For den stærkt reformistiske danske enhedsfagbevægelse medfører krisens trussel mod dens funktionsimperativ kun i beskedent omfang legitimitetsproblemer overfor dens medlemsbasis. ${ }^{23}$ Det er således ikke p.g.a. en legitimitetskrise for den socialdemokratiske fagbevægelse, men langt

21. Vi skal ikke her gå nærmere ind på den teoretiske bestemmelse af fagforeningerne, herunder de basale samfundsmæssige strukturer, der udgør grundlaget for etableringen af reformismen i fagbevægelsen. Se Redaktionskollektiv Gewerkschaften: Betingelser for socialistisk fagforeningsarbejde, i Kurasje 11, hvis grundpositioner også er dækkende for vores.

22. Redaktionskollektiv...op. cit. p. 31 .

23. Vi kan ikke indenfor artiklens rammer gå ind på en nærmere fremstilling af udviklingen af de oppositionelle bevægelser i fagbevægelsen - men blot konstatere det i denne sammenhæng afgørende, at de på intet tidspunkt udgjorde en egentlig trussel mod det socialdemokratiskreformistiske hegemoni. 
snarere som en konsekvens af reformismens grundmurede opfattelse af staten som et neutralt, funktionaliserbart instrument i kampen for socialismen (udvidelsen af arbejderklassens samfundsmæssige indflydelse), at den socialdemokratiske ledelse af fagbevægelsen i denne situation logisk nok vender sig mod staten for i nødværge overfor krisen gennem den statslige politik at søge fagbevægelsens interesser varetaget og dermed sin position sikret.

For Socialdemokratiet medfører rollen som statsbærende parti endnu ved krisens udbrud et dilemma mellem at føre en krisepolitik, der forbedrer kapitalens akkumulations- og eksistensbetingelser og at varetage arbejderklassens interesser. Også i Danmark løses dette dilemma gennem en politik, der underordner arbejderklassens umiddelbare interesser $\mathrm{i}$ at sikre reallønnen og $\emptyset$ ge beskæftigelsen under kapitalens akkumulationsbehov, ${ }^{24}$ kombineret med en statslig politik, der søger at afbøde krisens værste virkninger overfor arbejderklassen. Presset på udviklingen henimod den kooperative fagforeningspolitik og den tendentielle underlæggelse under statens funktionsimperativ udgår således i nok så høj grad aktivt fra staten. ${ }^{25}$

Men endelig som konsekvens - og dette er blot bagsiden af medaillen - så medfører udviklingen under krisen faktisk at reformismen i fagbevægelsen styrkes eller fastholder sin dominans. Godt nok medfører den statslige politik overfor arbejdsmarkedet partielt en inddragelse af lønfastsættelsen og lønudviklingen i krisereguleringspolitikken, der på den ene side kun i ringe grad formår at dæmme op overfor kapitalisternes direkte løntrykspolitik, mens den på den anden side betyder en afgørende fordyrelse af arbejderklassens leveomkostninger. Samtidig sker der gennem udviklingen af det retlige reguleringssystem på arbejdsmarkedet en begrænsning af arbejderklassens traditionelle kampmuligheder; altså alt i alt en politik, der objektivt skulle skærpe legitimitetsproblemerne for det reformistiske hegemoni. Men overfor dette skal fremhæves tre forhold af afgørende betydning for forklaringen af at resultatet bliver den modsatte udvikling.

For det første er den danske produktionsstruktur præget af en kraftig dominans af den agrare sektor og en udpræget hjemmemarkedsbaseret, hånd-

24. Dette betyder på grund af den agrare sektors dominans og store betydning for den industrielle sektor, at det mest omfattende element i den statslige kapitalstøttepolitik er ordninger omkring landbrugsproduktionen, der medfører et stærkt stigende, kunstigt højt hjemmemarkedsprisniveau for fødevarer, hvilket er kraftigt medvirkende til reallønsfaldet.

25. At dette ikke er et specifikt dansk fænomen turde være velkendt. Det er overhovedet den almene udviklingstendens for alle kapitalistiske lande i 30'erne, hvor arbejderklassens organisationer ikke ligefrem knuses af en fascistisk stat - en udvikling der er så meget desto mere accentueret, hvor der er et sammenfald af reformistisk hegemoni i fagbevægelsen og socialdemokratisk deltagelse i regeringsmagten. 
værkspræget og små-kapitalistisk industriproduktion. Dette betyder på den ene side, at dynamikken i den danske kapitalismes udvikling er bestemt udfra den gennemkapitaliserede landbrugsproduktion og ikke udfra den industrielle kapitals udvikling, og på den anden side, at arbejderklassen er meget heterogent sammensat og ikke udgør det afgørende, dominerende element i den danske klassestruktur. ${ }^{26}$ Denne industristruktur modsvares af en organisationsstruktur i fagbevægelsen, der hviler på reminicenserne af et laugssystem, hvor arbejderne organiseres efter faglig uddannelse og hvor de ufaglærte - arbejdsmænd, specialarbejdere og landarbejdere - organiseres for sig, hvilket tenderer mod at fastholde interessemodsætningerne mellem de forskellige arbejdere.

For det andet betyder gennemførelsen af arbejdsmarkedspolitikken, hvis væsentligste sigte som fremhævet er at »skabe ro « gennem konfliktindkapsling og institutionalisering af klassekonflikten, en styrkelse af centralismen i fagbevægelsen, såvel indenfor den enkelte fagforening som indenfor Landsorganisationen, hvilket begrænser mulighederne for en militant, fagoppositionel politik og dermed styrker den reformistiske position.

Hertil kommer - omend det er mindre vigtigt for denne periode - at der med den begyndende solidariske lønpolitik indenfor dele af fagbevægelsen skabes en vis relativ forbedring af de laverelønnedes vilkår - eller snarere en fordeling af krisens armod.

Endelig indeholder kriseinterventionspolitikken en vis kompensation overfor arbejderklassen i form af offentlige beskæftigelsesarbejder - herunder en kraftig udbygning af infrastrukturnettet - konkrete nødhjælpsforanstaltninger og væsentligst en samlet sociallovsreform, der for det første betød forbedrede muligheder for at opnå offentlig socialhjælp for den store gruppe af arbejdsløse, der p.g.a. langvarig arbejdsløshed ikke længere var berettiget til arbejdsløshedsunderst $\varnothing t t e l s e$, men som for det andet betød en forbedring af arbejdsløshedsforsikringen og en udvidet mulighed for at oppebære støtte. Krisen danner således baggrunden for det endelige gennembrud af socialstatspolitikken i Danmark og dermed også grundlaget for udbygningen af den reformistiske socialstatsillusion, der er afgørende for den kooperative fagforeningspolitik. Hertil kommer, at der efter den voldsomme eksplosion i arbejdsløsheden til et årligt gennemsnit på ca. 30\% i de to første kriseår igen sker et fald til et gennemsnit på ca. 20\% i resten af perioden. At dette i langt højere grad skyldes det totale sammenbrud af verdensmarkedet med den deraf følgende mulighed for en vis ekspansion i den hjemmemarkedsbaserede produktion og i langt mindre grad skyldes den beskæftigelsespolitik, der er indeholdt i

26. Således udgør lønarbejderne kun godt $1 / 3$ af den erhvervsaktive del af befolkningen. 
krisepolitikken, er i denne forbindelse ligegyldigt. ${ }^{27}$ Afgørende er nemlig, at det som resultat bidrager til opretholdelsen af legitimationsgrundlaget for den førte krisepolitik såvel for fagbevægelsen som for Socialdemokratiet.

Forudsætningerne for den »reformistiske klassekampsstrategi«, der hviler på den demokratiske samarbejdsmodel mellem fagbevægelse og stat, er således for Danmarks vedkommende udviklet gennem krisen i 30'erne, bl.a. baseret på eksistensen af en svag arbejderklasssee, såvel størrelsesmæssigt som p.g.a. sin heterogenitet, og en fagbevægelse, der i varetagelsen af sin funktion må vende sig til arbejderbevægelsens »politiske repræsentant«, Socialdemokratiet, for via staten dels at gennemtvinge opretholdelsen af de ydre betingelser for salget af varen arbejdskraft gennem en tiltagende retligg $\varnothing$ relse af forholdet mellem kapital og arbejde, og dels i kampen om fordelingen af nationalproduktet at sikre arbejderklassen en »retfærdig « andel i det mindste gennem den såkaldte sekundære fordeling, hvis akkumulationsbetingelserne og styrkeforholdet mellem klasserne ikke muliggør det gennem det autonome overenskomstsystem.

Med udgangen af 30'erne er der skabt de nødvendige og optimale politiske forudsætninger og strukturer for gennemførelse af en langsigtet lønstyring, uden at dette er baseret på direkte statslig lønfastsættelse med alt hvad dette medfører af legitimitetsproblemer. Det er imidlertid vigtigt at understrege, at der hermed blot er udviklet de nødvendige samfundsmæssige former gennem hvilke en sådan politik kan sætte sig igennem. Den statslige politik overfor arbejdsmarkedet havde ingenlunde dette sigte, men som fremhævet primært et andet, nemlig konfliktinddæmning.

\section{Den solidariske lønpolitik}

Det forekommer umiddelbart indlysende at det ikke er muligt at diskutere indkomstpolitik uden at diskutere fagforeningernes lønpolitik. Men i Sverige og Danmark er dette så meget desto mere påkrævet, som fagforeningernes

27. Der er således i den førte krisepolitik -i modsætning til forholdene under den socialdemokratiske regering i Sverige - ikke tale om fors $\varnothing \mathrm{g}$ på keynesiansk »pumppriming «. Tværtimod styres der eksplicit - som i det bedste husholdningsregnskab - efter et balanceret budget, hvilket i flere tilfælde medfører at staten og kommunerne udskriver ekstraskatter for at kompensere for de $\emptyset$ gede udgifter til arbejdsløshedsunderstøttelse, socialhjælp, beskæftigelsesarbejder m.v. Den keynesianske reguleringsmodel bliver, som fremhævet tidligere først i efterkrigstiden en del af den socialdemokratiske politik. 
lønpolitik her må opfattes som en af de væsentligste forudsætninger for den specielle skandinaviske socialdemokratiske lønstyring. Denne lønpolitik den solidariske - er sammen med arbejdsmarkedsstrukturen den vigtigste betingelse for, at den socialdemokratiske statslige lønpolitik kan begrænses til rammestyringen.

Forudsætningen for, at fagforeningernes lønpolitik overhovedet kan gøres til styringselement i en statslig politik, ligger i forhandlingsstrukturen på arbejdsmarkedet. Braun har som mange andre politikrådgivere set dette:

»Arbejdsmarkedsstrukturens rolle som et vedvarende instrument i afgørelsen af indkomstpolitikkens gennemførlighed og effektivitet kan næppe overvurderes. Eksistensen af stærke centrale organisationer ... for lønarbejdere og arbejdsgivere var en væsentlig faktor, der muliggjorde opfyldelsen af løn og prispolitikkens mål i Holland og Skandinavien over længere perioder: Dette beror især på at »centrale lønforhandlinger betyder, at generelle økonomiske og sociale overvejelser ikke kan holdes ude af forhandlingerne og løsningerne, således som det er muligt, hvor forhandlingerne foregår branche for branche eller på virksomhedsniveau «. ${ }^{28}$

De stærke, centraliserede fagforbund skal i denne institutionaliserede reguleringsform påvirke det samlede lønnivau. Kun fagbevægelsen besidder legitimitet til at tage de samfundsmæssige, fordelingspolitiske hensyn, der gør, at lønniveauet kan holdes inden for »forsvarlige « rammer. De fordelingspolitiske hensyn tilgodeses i de centrale forhandlinger (de generelle lønaftaler). På den anden side skal det også være således, at fagbevægelsens lønpolitik er bindende i alle de lokale, decentrale lønaftaler. Og her opstår der hyppigt problemer, da de to hensyn er modsigelsesfulde.

De decentrale lønforhandlinger ligger i Danmark i det såkaldte minimallønsområde (det bevægelige lønsystem), hvor lønnen som oftest er produktivitetsbundet. Det betyder, at produktivitetsstigninger i princippet udløser decentrale forhandlinger, der resulterer i decentrale lønforhøjelser. Det vil sige, at der på det decentrale forhandlingsområde er en tendens til løndifferentiering og spredning mellem brancher og fag, afhængig af branchernes produktivitetsudvikling.

I hele forhandlingssystemet og fagforeningernes rolle i den institutionaliserede reguleringsform ligger der således en modsigelse mellem de hensyn af samfundsmæssig, fordelingspolitisk art, som fagbevægelsen må tage, og de decentrale, bedriftsnære hensyn, hvor fagforbundene varetager hver deres særgruppeinteresser ud fra de særlige betingelser, som gælder for hver enkeltkapital.

28. Braun op.cit. p. 24 og 29 . 
Men denne modsigelse, som er et af de centrale omdrejningspunkter for den internationale indkomstpolitiske debat er løst dobbelt i først og fremmest Sverige, men også i Danmark. Meget centraliserede lønforhandlinger betyder minimering af mulighederne for at særinteresserne kan sætte sig igennem. Desuden kanaliseres indløsningen af særinteresserne ind i regulerbare former. Det vigtigste element i løsningen ligger i, at den socialdemokratisk dominerede fagbevægelse i Skandinavien gennem et langt historisk forløb har udviklet en lønpolitik som forener de to modstridende hensyn, muligvis kun for en periode. I det følgende vil vi vise, at de reelle virkninger af denne solidariske lønpolitiks sikring af en almen lønstigningstakt gennem en nivellering af lønstrukturen, som ikke rækker ud over det samfundsøkonomisk forsvarlige, dvs. produktivitetsudviklingen. Solidarisk lønpolitik er efter vores tese således ensbetydende med a) et produktivitetsorienteret lønniveau, og b) en tendentiel lønudligning (mindre løndifferentiering og -spredning), samtidig med c) at den fungerer som »sammenholdsfaktor « mellem de modstridende særgruppeinteresser. ${ }^{29}$

Tager vi det sidste punkt først, så kunne man også sige, at den solidariske lønpolitik tager sigte på at ophæve konkurrencen mellem arbejderne, og som sådan hænger den meget snævert sammen med bestemmelsen af fagforeningerne, hvorefter det gennem monopoliseringen af salget af varen arbejdskraft overhovedet muliggøres for fagforeningerne at få prisen på arbejdskraften til at svinge omkring dens værdi.

Dette element i den solidariske lønpolitik betyder ideelt set, at et bestemt konkret arbejde har én, og kun én pris, uafhængigt af hvilken enkeltkapital der køber det konkrete arbejde. Lønnens størrelse følger arbejdets art, ikke arbejderen eller virksomheden. Det betyder, at anvendelsen af det mindre kvalificerede arbejde, som muliggøres gennem teknologiske ændringer ifølge fagforeningernes solidariske lønpolitik i princippet skal betales lige så højt som det mere kvalificerede arbejde.

29. At dette sidste punkt ikke blot er en medfølgende omstændighed ved en bestemt overenskomstpolitik men i den socialdemokratiske selvforståelse er et vigtigt selvstændigt element fremgår af følgende citat af den socialdemokratiske økonom Henrik Heie: »Solidarisk lønpolitik ... er lige så gammel som fagbevægelsen - måske endda endnu ældre, idet den er forudsætningen for opbygningen af de faglige organisationer, at der føres solidarisk lønpolitik...Solidarisk lønpolitik er således en integreret del af den på arbejdsmarkedet opbyggede organisationsstruktur.... « Senere kommenterer Heie et forslag om afskaffelse af den solidariske lønpolitik »Resultatet af dette ville blive et sammenbrud i fagbevægelsens organisatoriske opbygning, som den idag ser ud. Fagforeningerne ville have udspillet sin rolle som lønpolitisk organ, dvs. ikke længere have mulighed for at fortsætte og derfor heller ikke for at varetage de opgaver, som påvirker udbudssiden på arbejdsmarkedet.« Heie i: Stabiliseringspolitik under fuld beskæftigelse. Kbh. 1967 p. 90 og 92 . 
Dette konkurrenceophævende moment i den soliariske lønpolitik blev tidligt i de skandinaviske lande opfattet som en ganske særlig fordel for arbejderbevægelsen. Allerede i tyverne kunne Stauning beskrive det specielle ved de danske forhold som den reducerede indbyrdes konkurrence mellem faglærte og ufaglærte. Dette er af særlig betydning her, fordi fagforeningerne som anført er organiseret efter fag. Den solidariske lønpolitik ophæver tendentielt gruppeinteresserne mellem de fagligt organiserede fagforeninger, især når den er kombineret med en stærk central magtudøvelse.

Det andet element i den solidariske lønpolitik gør den specielt reformistisk: Den fremmer ligheden og indkomstudligningen, fordi den generelt giver større lønforhøjelser til de lavestlønnede. Det er altså et element som baserer sig på forestillingen om en lønkage. Indenfor den lønsum, som står til rådighed som resultat af overenskomstforhandlingerne, skal og kan lønforholdene for de marginale lavtlønsgrupper - kvinder og ufaglærte - forbedres. Det fundamentale fordelingsforhold mellem kapital og arbejde bliver derimod ikke nævneværdigt ændret af den solidariske lønpolitik.

Bindingen til lønkageforestillingen betyder, at de enkelte fagforeninger må afstå fra at forsøge at udnytte de specielle muligheder indenfor deres eget fagområde, dvs. de må opgive særinteresserne til fordel for fællesinteressen. Denne proces er ikke foregået uden kampe mellem fagforeningerne, og det er betegnende i denne sammenhæng, at fagbevægelsens centrale magtorganer flere gange har forsøgt at udnytte specielle produktivitetsstigninger til at tvinge krav om ekstraordinære lønforhøjelser igennem. I tilfælde hvor disse særlige krav er blevet forsøgt gennemført ved vilde strejker, er der også flere eksempler på at fagforbund eller LO har medvirket til at dømme fagforeninger til at betale bod til arbejdsgiverne.

Vi hævder ovenfor sammen med Redaktionskollektiv Gewerkschaften, at fagforeningsorganiseringen betød en ophævelse af den indbyrdes konkurrence mellem arbejdskræfterne. Men »den fagforeningsmæssige organisering betyder ikke nødvendigvis forening af alle arbejdere overfor kapitalen, konkurrencen kan reproduceres mellem forskellige fagforeningsorganisationer og indenfor samme i en form hvor dele af arbejderne forsøger at afsondre sig monopolistisk fra andre dele af arbejderne. $\ll^{30}$ Den solidariske lønpolitik er den centraliserede fagbevægelses forsøg på at mindske også denne konkurrence om fordelingen af den samlede lønsum.

Mens vi således hidtil har set den solidariske lønpolitik udfra fordelingen af den samlede lønkage, så rejser sig nu spørgsmålet om hvordan kagens størrelse fastlægges dvs. hvordan ser den solidariske lønpolitik ud som konkret overenskomstpolitik, der skal fastlægge lønniveauet. Principielt

30. Redaktionskollektiv op. cit. p. 33. 
binder den solidariske $1 \varnothing$ npolitik ${ }^{31}$ hele lønudviklingen til produktivitetsudviklingen både den »samfundsmæssige produktivitet« og produktiviteten i industrien. Denne produktivitetsbinding ligger for så vidt i selve lønkage teorien, men det er først med det store opsving i den danske kapitalakkumulation i slutningen af halvtredserne og begyndelsen af tresserne, at hindringen formaliseres til aftaler om produktivitetsfremmende lønsystemer. Først med krisens gennemslag og massearbejdsløsheden begynder fagbevægelsen at stille spørgsmål ved rationaliteten i denne sammenkobling mellem løn og produktivitet på et tidspunkt, da arbejdsgiverne hjulpet af krisen forlængst har revet forbindelsen over. ${ }^{32}$

En aflønning af denne slags vil generelt føre til en forøgelse af udbytningsraten ved at fordelingsforholdet bliver forskudt til fordel for kapitalen. Og det er da også den solidariske lønpolitisk resultat, hvilket bliver tydeligt i tabel 2.

31. Den solidariske lønpolitiks indhold og virkemåde diskuteres også af Peter Søndergård, Løndifferentiering og overenskomst, i: Politiske arbejdstekster, 11-12, dec. 1977, men under en lidt anden synsvinkel. I modsætning til den fremstilling, som vi giver her, fremhæver PS, at overgangen til de produktivitetsfremmende lønsystemer er en alvorlig hindring for gennemførelsen af den solidariske lønpolitik (s. 89). Anvendelsen af produktivitetsfremmende lønsystemer fører efter vores opfattelse ikke til, at fagbevægelsens samlede lønpolitik må karakteriseres »differentieret« i modsætning til »solidarisk«, snarere tværtimod.

32. Det bevægelige lønsystem, den decentrale lønfastsættelse, eller minimallønsystemet blev allerede fra tressernes begyndelse lagt for had af de borgerlige $\varnothing$ konomer og politikere, som en væsentlig kilde til periodens inflationsproblem, og som en hindring for en effektuering af statslige indkomstpolitiske foranstaltninger til lønstyring. Arbejdsgiverne har under hele højkonjunkturen imidlertid støttet fagforeningernes kamp for dette lønsystem, fordi det muliggør en effektiv arbejdskraftallokering. (Derimod har arbejdsgiverne hele tiden bekæmpet pristalsreguleringen). I løbet af de første kriseår 1974-77 har arbejdsgiverne foranstaltet et angreb på dette 1ønsystem, ikke blot for at mindske lønpresset og fjerne de »legale« kampmuligheder, som systemet giver, men også for på længere sigt at disciplinere og svække de fagforeninger, som hidtil har været stærke som følge af den nødvendighed, som minimallønsystemet skaber for en vis aggressiv eller militant fagforeningspolitik. 
Tabel 2:

\section{Reallønsudvikling og produktivitetsudvikling (industrien).}

Stigning i procent i forhold til foregående år og index med $1964=100$.

\begin{tabular}{lcccc}
\hline År & $\begin{array}{c}\text { Realløns- } \\
\text { stigning }\end{array}$ & $\begin{array}{c}\text { Produktivi- } \\
\text { tetstigning }\end{array}$ & Realløn & Produktivitet \\
\hline 1959 & - & 6.2 & 81 & index \\
1960 & 3.8 & 3.4 & 84 & 76 \\
1961 & 8.2 & 6.4 & 91 & 78 \\
1962 & 1.9 & 5.7 & 93 & 88 \\
1963 & 3.6 & 3.9 & 96 & 92 \\
1964 & 4.3 & 9.1 & 100 & 100 \\
1965 & 5.4 & 1.3 & 105 & 101 \\
1966 & 4.3 & 6.1 & 110 & 108 \\
1967 & 2.3 & 10.8 & 112 & 119 \\
1968 & 3.3 & 10.4 & 116 & 132 \\
1969 & 8.2 & 9.2 & 126 & 144 \\
1970 & 4.3 & 7.7 & 131 & 155 \\
1971 & 8.3 & 8.1 & 142 & 167 \\
1972 & 4.8 & 8.9 & 149 & 182 \\
1973 & 5.7 & 5.6 & 157 & 192 \\
1974 & 3.5 & 4.6 & 163 & 201 \\
1975 & 9.1 & 7.7 & 178 & 217 \\
1976 & 2.0 & 6.1 & 181 & 230 \\
1977 & $\div 0.9 *$ & & $180^{*}$ & \\
\hline
\end{tabular}

Kilde og beregningsmåde se bilag s. $55 \mathrm{ff}$.

1) jvf. bemærkningerne i bilaget om produktivitetsberegningen.

* estimeret udvikling - jvf. bilaget.

Produktivitetsstigningerne overstiger langt reallønsstigningerne. ${ }^{33}$ Lønudviklingen formår ikke at fatholde en konstant udbytningsrate.

33. Tilsvarende resultater omkring forholdet mellem produktivitets- og lønudvikling ses i P. Dencik, Solidarisk Lønpolitik, i: Arbete, kapital och stat, 1974 og hos Phelps Brown, som for Sveriges vedkommende har beregnet denne udvikling for hele dette århundrede og finder, at produktiviteten konstant har ligget over reallønsstigningen. Jfr. International Economic Journal 1973. 
Det er naturligvis umuligt at udskille den solidariske lønpolitik som eneste årsag til denne konkrete udvikling, idet en lang række af de ovennævnte faktorer også må indgå i forståelsen af udviklingen. Det er derfor mere korrekt at betragte tabellen som udtryk for virkningen af den specielle kooperative lønpolitik, hvori den solidariske lønpolitik ikke blot er den overenskomstpolitiske, taktisktekniske del, men hvor den også danner det langsigtede politiskideologiske element.

I praksis gennemføres bindingen mellem løn og produktivitet, således at hovedorganisationerne ved begyndelsen af overenskomstforhandlingerne udarbejder et fælles grundlag for vurderingen af produktivitetsudviklingen i den forløbne periode. Når denne fælles rationalitet (som er et forhandlingsresultat og ikke engang i deres selvforståelse et objektivt mål) er etableret, kan de egentlige forhandlinger om den samlede lønstigning indledes, dvs. fordelingen af produktivitetsstigningen mellem kapital og arbejde. Den fastlagte gennemsnitlige produktivitetsstigning danner grundlaget eller rammerne for overenskomstforhandlingerne, og det er vigtigt at fremhæve, at den solidariske lønpolitik medfører, at alle fagforeningsmedlemmer forlanger hhv. får ensartede lønforhøjelser, da de forskelligartede krav fra fagforeningerne jo transformeres til ensartede krav af den centrale fagbevægelses forhandlingsorganer. Lønforhøjelserne er således uafhængige af enkeltkapitalers virkelige produktivitetsudvikling og kun i overensstemmelse med den gennemsnitlige udvikling.

Ved fremstillingen af de forskellige elementer i denne reformkapitalistiske model kan det let i den sammentrængte, og ikke historisk udfoldede form, der her har fået, ske, at modellen fremtræder mere gennemtænkt, reflekteret i sine forskellige $\varnothing$ konomiske og politiske konsekvenser, end den faktisk er. Der kan ganske vist trækkes eksempler frem på, at Socialdemokratiet og fagbevægelsen arbejder og tænker i sådanne styringsmodeller ${ }^{34}$, men meget tyder på, at det danske Socialdemokratis politiske og økonomiske strategier snarere er bestemt af de dagsaktuelle krav og den aktuelle situation. Imidlertid er det vigtigt at forstå den reformkapitalistiske strategi i sin »rene« form, fordi stadig flere elementer af denne udbyggede model finder vej til selv danske venstrefløjssocialdemokraters lønkamre og i en vis udstrækning tilsyneladende har fagbevægelsens bevågenhed - det gælder f.eks. de sidste års udspil fra Arbejderbevægelsens Erhvervsråd. Derfor vil vi kort prøve at se på den »svenske model « eller arbejdsmarkeds- og lønpolitik hvor disse elementer er udviklet renere. En svensk LO- $\varnothing$ konom, Anders Leion, har beskrevet den svenske model på følgende måde:

34. Jvf. f.eks. DASFs »betænkning fra lavtlønsudvalget« p. 63 her taget fra Peter Søndergård, Løndifferentiering og overenskomst, i Politiske arbejdstekster nr. 11, 1978. 
»Det var statens opgave med skatte- og kreditpolitik at holde den totale efterspørgsel....inden for $\emptyset$ konomiens produktionsformåen. Dette måtte dog ikke indebære, at alle virksomheder skulle kunne finde afsætning for deres produkter. I så fald ville efterspørgslen blive så høj, at den efterfølgende almene prisstigning ville føre til at også foretagender med de højeste omkostninger kunne sælge deres produkter....

Man måtte føre en sådan politik, at ikke alle igangværende virksomheder kunne overleve. Det ville medføre virksomhedsnedlæggelser og driftsindskrænkninger og dermed også arbejsløshed... Det var imidlertid ikke tilstrækkeligt at staten førte en udfra disse synspunkter fornuftig økonomisk politik. Hvis de ansatte i de ikkeprofitable virksomheder hellere ville sænke ders løn end flytte til andre arbejdspladser, så ville denne politik umuliggøres. Virksomhederne måtte derfor presses fra to sider: dels gennem at efterspørgslen blev holdt tilbage, og dels ved at lønningerne pressedes op, uanset hvilken profitabilitet en bestemt branche eller virksomhed blev drevet med. Derigennem skulle det almene gevinstniveau blive så lavt, at højomkostningsvirksomhederne blev tvunget til lukning... « Herved blev »de mest profitable virksomheder gavnet: på trods af at de i mange tilfælde ville have muligheder for at bære mere end de gennemsnitlige lønstigninger blev der ikke rettet større lønkrav til dem end til de svage virksomheder. Følgen blev naturligvis, at disse foretagender fik meget høje gevinster.

Disse gevinster var både noget velkomment og et problem. Efter som hensigten bl.a. var at fremme strukturændringerne - for derigennem at $\varnothing \mathrm{ge}$ indkomsterne og sikre arbejdspladserne - var de høje gevinster et godt middel til at finansiere... udbygningen af de produktive virksomheder. Men det førte også til, at arbejderne i disse virksomheder måtte betale ekspansionen ved at afstå fra mulige $1 \varnothing n f o r h ø j e l s e r . . . \ll^{35}$

Den solidariske lønpolitiks strukturrationaliserende virkninger skaber imidlertid et problem. Da lønpolitikken virker rationaliserende, skaber den samtidig arbejdsløshed, fordi produktivitetsudviklingen for så vidt den også er en produktivkraftudvikling, forøger kapitalens organiske sammensætning og dermed tendentielt formindsker beskæftigelsesgraden. Denne arbejdsløshedsskabende virkning betyder, at fagforeningerne sætter en ydre forudsætning op for at følge en solidarisk lønpolitik, nemlig at den til en hver tid siddende regering fører fuldbeskæftigelsespolitik. På grund af den organisatoriske sammenhæng mellem fagforeningerne og Socialdemokratiet lader denne ydre forudsætning sig bedst opfylde når regeringen er socialdemokratisk. Hermed fremtræder to direkte virkninger af en socialdemokratisk regeringsmagt: for det første en lønudvikling, der halter bagefter produktivitetsudviklingen, og for det andet 
en aktiv fuldbeskæftigelsespolitik, som ikke kun er uproduktiv anvendelse af arbejdskræfterne. I Sverige har man således meget tidligt udarbejdet denne nødvendige forudsætning under betegnelsen aktiv arbejdsmarkedspolitik.

I relation til arbejdskraften indeholder dette politikfelt tre elementer: geografisk mobilitet, erhvervsmæssig mobilitet dvs. omskoling, og nødarbejde. I relation til kapitaldannelsen indeholder arbejdsmarkedspolitikken en særlig form for konjunkturel investeringskontrol gennem konjunkturudligningsfonden. Virksomhederne betaler i opgangsårene en vis del af overskuddet og kan så i nedgangsperioder modtage tilskud, hvis arbejdsmarkedsrådet finder det rimeligt, dvs. at der er tale om investeringskontrol i den forstand, at man vurderer, om investeringer udnyttes til at fremme produktivitet og rationalisering. ${ }^{36}$

Med denne gennemgang af den solidariske lønpolitik som centralt element i fagbevægelsens samlede lønpolitik og den (begyndende) aktive arbejdsmarkedspolitik som væsentlig forudsætning for den kooperative fagforeningspolitik, har vi angivet de to hovedelementer, som for en lang periode overflødigg ør en selvstændig statslig indkomstpolitik, forstået som indgreb i arbejdskontrakten. Vi betragter således gennemgangen af den solidariske lønpolitik og den statslige arbejdsmarkedspolitik her som en nærmere indholdsbestemmelse af det, som vi i indledningen kaldte »rammestyring «. Denne rammestyrings elementer og sammenhængen mellem dem er et særligt skandinavisk fænomen og er dermed også helt centrale bestanddele af den socialdemokratisk formede kapitalisme. I summarisk form kan man fremdrage følgende karakteristiske træk:

a) stærkt centraliserede lønforhandlinger.

b) en arbejdsretlig regulering, som indebærer, at de fleste konflikter transformeres til forhandlings- og mæglingsspørgsmål. Der er generelt tale om få strejker i international målestok. For Danmarks vedkommende er en del af disse strejker ydermere illegaliseret som »vilde « på grund af fredspligten.

c) solidarisk lønpolitik som dominerende lønpolitisk mål i fagbevægelsen. Den solidariske lønpolitik fremmer en lønudligning mellem de forskellige arbejdergrupper. Samtidig fungerer den gennem lønsystemer, som binder lønudviklingen til produktivitetssudviklingen, hvorved myten om den retfærdige løn styrkes samtidig med, at udbytningsraten kan forøges.

36. Om den svenske kapitalakkumulations udvikling efter 1940 se Povl A.Hansen og Lennart Söderlund, Kapitalutvecklingen i Sverige, i Tekla 3\%4, Lund 1977. Heri gives også en fremstilling af arbejdsmarkeds- og strukturpolitikkens udvikling, samt en analyse af årsagerne til den »den svenske models« sammenbrud og den nuværende krise i Sverige. 
d) fuld beskæftigelse som det vigtigste mål for statens konjunkturpolitik, der bl.a. gennemføres via arbejdsmarkedspolitikken, hvor arbejdskraftens faglige og geografiske mobilitet forøges. Fuldbeskæftigelsesmålsætningen betyder også, at inflationsraterne generelt bliver større i de skandinaviske lande.

e) for Sveriges vedkommende er der ydermere tale om investeringskontrol som arbejdsmarkedspolitisk middel og som et led i en strukturrationaliseringspolitik.

Hele denne struktur har eller får en altafgørende betydning for profitproduktionen. Den gør det muligt at holde reallønnens stigningstakt under produktivitetens stigningstakt. Det betyder, at man langt hen ad vejen har »løst « kapitalismens grundlæggende modsigelse mellem arbejdsløn og profit: de vokser begge samtidig, omend profitten vokser hurtigst. Så længe denne mekanisme virker, er enhver yderligere lønregulering ikke alene overflødig, men også politisk skadelig. Mekanismen virker dog ikke altid, hvor fejlen for så vidt ikke ligger i strukturen som sådan, men i de ydre betingelser for dens effektivitet, som kort fortalt er eksistensen af en økonomisk vækst, dvs. en gunstig akkumulationstilstand. Når de ydre rammer forandres, når der forekommer en økonomisk afmatning og endnu værre når der forekommer krise, trues en række af de nævnte strukturelle former også af opløsning, samtidig med at deres effektivitet mindskes. Under krisesituationen i dag er udviklingstendenserne i de anførte punkter a-d vendt fuldkommen om: der er nu et voksende pres for mere decentrale lønforhandlinger, der er et stærkt voksende antal strejker og også tale om et pres mod selve den retlige regulering af arbejdsmarkedet (kamp mod arbejdsretten), der er tale om en begyndende

opløsning af den solidariske lønpolitik og måske også voksende spredning i arbejdslønningerne og endelig har inflationsbekæmpelse fået prioritet over den fulde beskæftigelse som konjunkturpolitisk målsætning. Dermed er muligheden for rammestyring ikke længere til stede, og indkomstpolitikken bliver statens svar.

Vi skal i det efterfølgende afsnit uddybe denne sammenhæng mellem konjunkturbevægelse og indkomstpolitik.

\section{Den indkomstpolitiske udvikling}

Det er flere gange ovenfor blevet fremhævet, at det er afgørende at analysere de statslige politikformer i deres akkumulationsmæssige sammenhæng. Fastholdes den konkrete statslige $\varnothing$ konomiske politiks fundamentale afhængighed 
af kapitalens akkumulationsbevægelse ikke, bliver alle statslige indgreb, trods deres forskellige formål og indhold qua deres form forskelsløst kategoriseret som indkomstpolitik fra indgrebet i dagbladskonflikten i 1908, over truslen om indgreb i overenskomsten i 1925 til de talrige indgreb mod slagteriarbejderne i 50 'erne og tresserne. Den komparative politologi kan fejre nye triumfer i sammenligningen mellem Kanslergadeforliget, indgrebet i 1956 og Helhedsløsningen i 1963.

Men ydermere betyder en sådan tilgang, hvor man ikke fastholder denne sammenhæng, at man mister muligheden for en mere præcis afgrænsning af nødvendigheden i og grænserne for en statslig indkomstpolitik og dermed i et større perspektiv afskærer sig fra vurderinger af dens potentialer som led i en statslig kapitalstabiliseringspolitik. Vi vil derfor i dette sidste afsnit dels uddybe bindingen af indkomstpolitikken som lønpolitik til problemerne i selve kapitalakkumulationen, altså se på lønnens betydning i akkumulationsprocessen. Dernæst diskuteres den indkomstpolitiske udvikling siden tressernes begyndelse ved at unders $\varnothing$ ge nogle af de centrale indkomstpolitiske initiativer udfra den forudgående diskussion.

Hvis vi ser den almene formel for kapitalens kredsløb, $\mathrm{P}-\mathrm{V}_{\mathrm{Pn}}^{\mathrm{Ak}} \ldots . .$. Produktionsproces.... V' - P', som et udtryk for de forskellige metamorfoser kapitalen må gennemløbe i sin reproduktions- og akkumulationsproces, så optræder lønnen her i to forskellige funktioner, nemlig dels som omkostningsfaktor for kapitalen i den første metamorfose, hvor en del af pengekapitalen forvandles til produktiv kapital gennem købet af varen arbejdskraft på arbejdsmarkedet (P-A), dels som konsumfond for arbejderen for hvem dette led i den første metamorfose blot er det første led i hans egen cirkulation $(\mathrm{A}-\mathrm{P}-\mathrm{V})$, der indeholder hans konsumtion og dermed reproduktion. Mens således det første led i denne såkaldte »lille cirkulation « indgår i kapitalens kredsløb, så falder det andet led - forvandlingen af lønnen til konsumtionsmidler - uden for selve kapitalkredsløbet, men optræder overfor kapitalen som arbejderklassens samlede efterspørgsel efter konsumtionsmidler. I disse to funktioner optræder lønnen også i den borgerlige økonomisk-politiske debat og dermed også i den statslige politikformulering - omend den indre sammenhæng med kapitalens reproduktions - og akkumulationsproces forbliver uforstået. Alt efter akkumulationens cykliske forløb er det således lønnen som omkostningsfaktor eller lønnen som efterspørgselsfaktor med deraf afledede virkninger for den samlede $\varnothing$ konomi, der rykker i focus som grunden til at gennemføre en indkomstpolitik, selv om betingelserne for kapitalakkumulationen fremtræder som vidt forskellige.

Politikfeltet er således alment bestemt til stadighed indgreb overfor lønudviklingen, men akkumulationscyklens forløb giver indgrebene forskelligt tyngdepunkt og sigte. 


\section{a) Indkomstpolitik med udgangspunkt i lønnen som efterspørgsels- faktor}

Under den langvarige opgangskonjunktur i tresserne er det altovervejende lønnens funktion som efterspørgselsfaktor, der er det centrale debatpunkt og problem for den statslige politikudformning, og kun i formidlet form lønnen i dens funktion som produktionsomkostningsfaktor for kapitalerne.

Den vedvarende vækst i akkumulationen muliggør en vækst i reallønnen uden at denne skaber begrænsninger i betingelserne for profitproduktionen og akkumulationen - og dette så meget desto mere som udviklingen er kendetegnet ved en produktivitetsudvikling, der er større end lønudviklingen (jfr. afsnittet om solidarisk lønpolitik) og akkumulationen er båret af en kraftig arbejdsintensivering.

Den $\varnothing$ konomiske vækst er imidlertid ledsaget af en stadig voksende inflation og for den danske situation yderligere af et tiltagende problem med betalingsbalanceunderskud. ${ }^{37}$

Den statslige politik forholder sig til disse generelle, nationale $\varnothing$ konomiske problemer, og her bliver efterspørgselseffekten af lønudviklingen det centrale anknytningspunkt $\mathrm{i}$ forsøget på at mindske det private konsum og på den måde lægge en dæmper på inflationen og rette op på betalingsbalancen. P.g.a. de arbejdskraftallokeringsproblemer, som den fulde beskæftigelse skaber i en fase med ekspansiv kapitalakkumulation, var en statslig indkomstpolitik - omend nok et tænkeligt redskab - ikke nogen hensigtsmæssig indgrebsform, og da der heller ikke var profitproduktionsproblemer i generel forstand heller ikke nogen nødvendig indgrebsform. Den $\emptyset$ nskede effekt søgtes derfor realiseret ved anvendelsen af de »klassiske « indgrebsmidler fra den keynesianske anticykliske interventionspolitik: finans- og delvis pengepolitikken.

I forbindelse med mindre internationale tilbageslag i kapitalakkumulationen, der også rammer Danmark og får en stadig voksende betydning p.g.a. synkroniseringen af krise- og akkumulationscyklen imellem de forskellige lande, opstår der økonomisk-politiske situationer, hvor også lønnen som omkostningsfaktor får akut betydning p.g.a. de indsnævrede internationale konkurrencevilkår. Sammenfaldet mellem voksende inflation, voksende betalingsbalanceproblemer og så egentlige profitproduktionsproblemer betyder, at der i disse situationer gennemføres eller forsøges gennemført

37. I forbindelse med inflationsdiskussionerne rykker lønnen som omkostningselement i focus specielt i cost-push diskussionen, men her netop i formidlet form. Altså ikke i form af begrænsning af enkeltkapitalernes profitproduktionsbetingelser, men i relation til konkurrencen om afsætningen (altså profitrealiseringsproblem) især på verdensmarkedet og således snævert forbundet med betalingsbalanceproblemet. 
statslige indgreb af egentlig indkomstpolitisk art. (Det drejer sig om 1963, $1967 / 68$ og 1970).

Men med disse undtagelser, som vi skal behandle mere indgående nedenfor, fastholdes den socialdemokratiske reformkapitalistiske model, hvor den egentlige styring af lønudviklingen varetages i ekstrastatslig regi gennem den kooperative fagforeningspolitik gennem hele 60'ernes opgangskonjunktur.

\section{b) Indkomstpolitik med udgangspunkt i lønnen som omkostningsfaktor}

I og med omslaget i akkumulationsbetingelser i 1973/74, hvor den begyndende internationale krise også sætter sig igennem overfor den danske kapital, sker der også et omslag i den statslige politik overfor lønudviklingen. Trods en vækst i produktiviteten, der til stadighed ligger over udviklingen i reallønnen, betyder de skærpede internationale konkurrencevilkår og den forringede profitabilitetssituation, at økonomisering med omkostningselementerne - og her først og fremmest lønomkostningerne - fra at være en permanent bestræbelse bliver en livsnødvendig betingelse for kapitalen. For den statslige politik betyder dette en vending på to punkter: Dels et omslag i den traditionelle keynesianske anticykliske politik, hvor den begyndende krise nu ikke mødes med en ekspansiv finanspolitik, men hvor man p.g.a. 'inflationseksplosion' og betalingsbalanceproblemer foretager begrænsninger på de offentlige budgetter, stramninger af pengepolitikken og begrænsninger i massekonsumet.

Dels forsøger man direkte eller indirekte nu at virke ind på lønnen som omkostningselement i produktionen: I første omgang med subsidiepolitik til kapitalerne til nedbringelse af lønomkostningerne og ved gennem skattepolitiske lettelser i indkomstbeskatningen at skabe baggrundsbetingelser for opbremsning i lønudviklingen, men i næste omgang, som vi skal se, i form af statslig lønpolitik og styring, indkomstpolitik.

Med krisen bryder således den socialdemokratiske reformkapitalistiske model sammen. Dens fundamentale grundlag, nemlig den fulde beskæftigelse og en stadig voksende realløn, der under den kooperative fagforeningspolitik ikke antaster kapitalens akkumulationsbetingelser, bryder sammen. Krisens realitet tvinger staten til at opgive den fulde beskæftigelse som et umiddelbart styringsmål og under indtryk af de stadige voksende kapitalkrav om sænkning af (løn)omkostningerne sker der en vending mod et i teoretisk forstand neoklassisk $\varnothing$ konomiskpolitisk instrumentarium: Ydre statslig lønbegrænsning, pres på fagbevægelsen i overenskomstafslutningen og accept af reservearméen som nødvendig for at kapitalen skal komme ud af sin profitabilitetskrise. 
Under stadig bibeholdelse af en række fundamentale elementer fra den socialstat, der er opbygget under socialdemokratiets auspicier bliver indkomstpolitikken rammen om denne nye politik. ${ }^{38}$

Vi har indtil nu fors $\varnothing \mathrm{gt}$ at vise, at arbejdslønnens betydning for kapitalen og staten varierer med akkumulationsprocessens udvikling, fordi arbejdslønnen altid optræder dobbelt: som efterspørgselsfaktor (arbejderklassens massekonsum og dermed reproduktion) og som omkostningsfaktor. Det betyder også, at den gennemførte eller $\emptyset$ nskede indkomstpolitik er forskellig i 1970'erne og 1960'erne, på trods af, at der formmæssigt er tale om en og samme politik. Dette skal vi nu undersøge ved en gennemgang af nogle konkrete indgreb/ indgrebsfors $\emptyset$.

\section{Indkomstpolitikken i 1960 'erne}

Kombinationen af den solidariske lønpolitik, produktivitetsbindingen, den statslige finans- og pengepolitiks anticykliske effekter og den danske kapitals akkumulationsforl $\varnothing b$ og verdensmarkedssammenfletning mindsker nødvendigheden af en indkomstpolitik med undtagelse af de tilfælde, hvor de akkumulationsmæssige betingelser momentant trues. Indkomstpolitikken er således ikke den strukturelt nødvendige politikform i denne periode. Men i disse enkeltstående tilfælde aktualiseres også problemet omkring lønnen som omkostningsfaktor, fordi den internationale recession, der finder sted omkring indgrebstidspunkterne naturligvis betyder en skærpet konkurrence for de danske kapitaler og dermed profitrealiseringsproblemer.

»Omkostningsproblemet « er netop kun momentant, fordi den generelle tendens i akkumulationsudviklingen i den kapitalistiske verden med hurtigt genoptagne kraftige vækstrater i de centrale økonomier afsvækker det danske »omkostningsproblem «.

I 1962/63 truer et mindre tilbageslag i alle ledende kapitalistiske lande det kraftige opsving som startede i 1959. Dette giver i løbet af 62 et stigende betalingsbalanceunderskud, kraftig inflation (set i forhold til den foregående periode), stigning i ledigheden og i løbet af 1963 stagnation i produktionen.

38. Krisen sætter sig sine umiskendelige spor i udfyldningen af de socialstatslige rammer og sikringssystemer. Således sker der jo en løbende forringelse af det offentliges serviceniveau, f.eks. udtrykt som nedskæringer på daginstitutioner, strammere administration af bistandslovgivningen og forringet SU. Men samtidig satser Socialdemokratiet øjensynligt hårdt på at fastholde niveauet på de direkte arbejdsmarkedsforbundne felter (f.eks. omkring fastholdelse af dækningsprocenten for arbejdsløshedsunderstøttelsen. løbende forlængelse af dækningsperioden osv.). Dette antyder, at de mulige legitimitetsproblemer omkring kernegruppen af socialdemokratiske vælgere er afgørende for socialdemokratiets politik. 
Samtidig med det voldsomme opsving i den industrielle akkumulation var betingelserne for landbruget blevet forværret, hvilket havde skabt uro blandt landmændene.

De meget høje nominallønstigninger i de to foregående år skabte sammen med den faldende ledighed grundlag for forestillinger om et lønskabt inflationspres. Regeringens (SD og R) første udspil i denne anledning var landbrugsst $\varnothing t$ teordninger og finanspolitisk stramning gennem indførelsen af omsætningsafgiften (oms). Men tilbageslaget aktualiserede yderligere indgreb og ved overenskomstforhandlingerne i 1963 greb regeringen ind med en pakkeløsning (Helhedsløsningen) som omfattede landbrugsordning, lønbegrænsning gennem en forlængelse af overenskomsterne, forbud mod strejker og pris- og avancestop.

Fagbevægelsen accepterede det indkomstpolitiske indgreb i et fors $\emptyset \mathrm{g}$ på at få lagt et loft over de finanspolitiske stramninger. Omsens indførelse året før havde skabt interesse for den disponible realløn (altså for arbejderklassens konsumfond eller umiddelbare reproduktionsniveau), fordi store nominelle lønstigninger i 1961 og 1962 og faktiske reallønsstigninger blev til et fald i den disponible realløn på grund af bl.a. denne finanspolitiske stramning. Desuden var viljen til samarbejde i fagbevægelsen også præget af, at fagbevægelsens mål gennem 20 år, fuld beskæftigelse, var nået, og at en socialdemokratisk styring af $\varnothing$ konomien synes bedst egnet til at fastholde denne situation. Viljen til samarbejde om en stabil udvikling i lønnen fik sit ypperste udtryk i protokollatet året efter mellem DA og LO, hvor lønnens binding til produktiviteten og begge parters vilje til at holde lønudviklingen indenfor det samfundsmæssigt ansvarlige fastslås. Det fornyede opsving mindsker dog nødvendigheden af opfølgende indkomstpolitiske initiativer.

Ved den internationale recession i 1967/68 aktualiseres de samme problemer blot $\mathrm{i}$ et lidt andet regi. Der er en vis stigning i betalingsbalanceunderskuddet, men det er konkret dels de tyske bestræbelser på at eksportere krisen gennem eksportfremstød og dels den engelske devaluering, som foranlediger en tilsvarende dansk aktion i form af en devaluering. Den socialdemokratiske regering fors $\varnothing$ ger at gennemføre en »følgelovgivning « til devalueringen $\mathrm{i}$ form af indefrysning af kommende dyrtidsportioner for at fastholde devalueringens konkurrencefordele. ${ }^{39}$ Igen er der således tale om en reaktion på krisen på verdensmarkedet, balanceproblemer (eller forventningen herom) og inflationsfrygt på baggrund af de to foregående års høje nominallønstigninger.

39. Vi ser her helt bort fra alle de parlamentariske problemer omkring »arbejderflertallet« og dermed også hvilken betydning dette måtte have haft for følgelovgivningens udformning og nødvendighed. 
VKR-regeringen forsøger gennem den første halvdel af 1968, hvor verdensmarkedskrisen slår igennem i Danmark at gennemføre en indkomstpolitisk løsning efter den tidligere socialdemokratiske linie. Ledigheden begynder at stige voldsomt, men fagbevægelsen har stadig kraft til at tvinge store lønstigninger igennem. Det afgørende er dog, at den nye opgangskonjunktur sætter sig hurtigt igennem på verdensmarkedet. Den trækker Danmark med uden indkomstpolitiske initiativer.

Mens den afgørende grænse eller betingelse for den $\varnothing$ konomiske politikformning i tresserne således er det nyskabte grundlag for den nationale akkumulation i slutningen af halvtredserne, den solidariske lønpolitiks fastholdelse af forholdet mellem løn og produktivitet, og verdensmarkedskonjunkturernes generelle opsving, så ændres disse grundlæggende betingelser i halvfjerdsernes begyndelse og dermed forandres grundlaget for politikformningen efterhånden.

\section{Indkomstpolitikken i 1970'erne}

Tressernes opgangskonjunktur med midlertidige kortvarige afmatningsperioder muliggør en fastholdelse ved den keynesianske anticykliske politik som generelt instrument i den $\varnothing$ konomiske politik, fordi profitabilitets- og balanceproblemerne kun stiller sig momentant.

Karakteristisk for 60'ernes indkomstpolitik og fors $\emptyset$ g herpå er således, at den forekommer på baggrund af en generel økonomisk opgang i situationer, der er kendetegnet af følgende fire forhold:

a) en momentan international afmatning

b) nationale betalingsbalanceproblemer

c) nationale inflationsproblemer

d) og et momentant nationalt profitproduktionsproblem - jfr. bilagstabellen om kapitalrentabilitetens udvikling.

Modsat forhindrer halvfjerdsernes stagflation og krise videreførelsen af denne politik, fordi den fjerner dens akkumulationsmæssige grundlag, og fordi den synkronisering af de vigtigste verdensmarkedslandes krisecykler ikke muligg ør, at den danske kapital udnytter lempelser i den internationale konkurrencesituation. Det er således kombinationen af svigtet i den nationale akkumulation - som giver sig udtryk i dels faldende profitrate og dels faldende produktiv akkumulation - og den samtidige krise på verdensmarkedet, som stiller hensynet til profitten i centrum for den $\emptyset$ konomiske politik.

Venstre-regeringen forsøger i 1974 at gennemføre VKR-regeringens mislykkede fors $\emptyset \mathrm{g}$ på at føre indkomstpolitik, men står ligesom denne overfor 
store legitimitetsproblemer i forhold til fagbevægelsen. Den manglende legitimitet i forhold til gennemførelsen af en politik, der rettes mod lønnen som omkostningsfaktor forstærkes af en utilsløret reaktionær politik på alle andre områder. Regeringen må derfor lade sig nøje med at yde statslige subsidier til kapitalen på samme måde som regeringen gjorde det i 1970 .

Ved valget i 1975 op til overenskomstsituationen kommer en socialdemokratisk regering til magten. Der er ingen tegn på opsving på verdensmarkedet, men fagbevægelsen har, tvunget af en høj kampaktivitet på arbejdsmarkedet under den borgerlige regering, lagt op til forholdsvis store lønforbedringer. ${ }^{40}$

Selvom den politisk- $\varnothing$ konomiske argumentation bag indgrebet i overenskomsterne entydigt retter sig mod lønnen som omkostning for den betrængte kapital, så får dette første indkomstpolitiske indgreb samme form af konfliktindkapsling og afværgemanøvre i en national katastrofesituation som indgrebene i trediverne og halvtredserne: Arbejdsmarkedets formelle autonomi fastholdes ved ophøjelsen af en mæglingsskitse til lov. Autonomien er imidlertid nu blevet en farce, idet regeringen som grundlag for loven måtte benytte et arbejdspapir fra forhandlingernes begyndelse, da parterne ikke engang havde kunnet blive enige om et mæglingsforslag. I realiteten var der med indgrebet tale om en tvangsmæssig forlængelse af gældende overenskomster med visse ubetydelige ændringer i lønsatserne for de lavestlønnede.

I løbet af 1976 indgås der flere politiske forlig, hvis funktion først og fremmest er at formalisere og videreføre den rensende virkning, som krisen har indledt. Vigtigst er det dog, at de kraftige lønforbedringer, som arbejderklassen på trods af stagnation og begyndende krise havde formået at fastholde fra højkonjunkturens sidste del, nu begynder at stagnere og vende fra midten af 1975.

Den socialdemokratiske politik er entydigt knyttet til håbet om sandhedsværdien af de mange internationale konjunkturforudsigelser, som på dette tidspunkt forudsiger et opsving i løbet af 1976. Der er for så vidt i den socialdemokratiske selvforståelse tale om en gentagelse af styringsfors $\emptyset$ gene fra tresserne, hvor ekspansion og kontraktion i statsfinanserne ligeledes var styret af politikrådgivernes spådomskunst og de internationale statistikkers forsinkede informationer.

Men opsvinget på verdensmarkedet udebliver eller flader i USAs tilfælde ud og situationen forværres ved, at den svenske kapital nu også geråder i krise.

40. Det er uvist om der var tale om en »aktionsplan« mellem SD og fagbevægelsen, der gik ud på, at LO skulle få forhandlingerne til at gå i hårdknude for at lette et socialdemokratisk forlig. Svend Auken antyder en sådan slagplan i Økonomi og Politik nr. 3, 1975 p. 268. 
Gradvist ændres Socialdemokratiets opfattelse af situationen og de nødvendige midler til en styring af økonomien: Akkumulationen skal sættes igang på nationalt grundlag, og der skal skabes forudsætninger for, at den danske kapital kan hænge med på et senere opsving, hvor konkurrencen i modsætning til tidligere opsving vil være uhyggeligt skærpet.

I august 1976 afstikker Socialdemokratiet forsøgsvis den nye kurs: Op til overenskomstforhandlingerne i 1977 fastlægges en maximumsgrænse for lønstigningerne i perioden frem til 1979. Den samlede lønsum må ikke stige mere end $6 \%$ pr. år.

For så vidt svarer 6\%-rammen til de rammer, der gennem 60'erne blev anbefalet af de фkonomiske vismænd som »samfundsmæssig ansvarlig « såvel hvad angår den numeriske størrelse som den svævende argumentation. Den afgørende forskel er, at lønudviklingen nu bliver dikteret fagbevægelsen, og at der er et stærkt politisk krav om, at rammen skal overholdes, hvor de borgerlige forsøger at fastholde Socialdemokratiet på en hård kurs overfor fagbevægelsen.

Valget i januar 1977, der skal lette gennemførelsen af indkomstpolitikken ved inden overenskomstfornyelsen at have gjort det til et omfattende politisk spørgsmål, styrker faktisk Socialdemokratiet, og ved overenskomstforhandlingerne tvinger regeringen i første række fagbevægelsen til at akceptere et mæglingsforslag, der formelt holder sig indenfor 6\%-rammen. Det blev dog alment antaget, at den samlede lønudvikling sandsynligvis vil følge nogenlunde med prisudviklingen, dvs. blive på ca. 10\% og af den grund forkaster arbejdsgiverne også mæglingsforslaget, der dernæst ophøjes til lov på ganske traditionel vis.

Et element i denne indkomstpolitik fortjener dog særlig opmærksomhed, nemlig bestemmelsen om at kun en dyrtidsportion må komme til udbetaling hvert halve år; hvis flere udløses skal de af staten indbetales i ATP-fonden. På trods af denne kluntede ordnings forsøg på at fastholde, at lønarbejderne jo ikke mister noget, men blot får overført en del af lønstigning til pensionsfonden, viser den dog netop helt klart, hvad indkomstpolitikken sigter på: nemlig lønomkostningsreduktion for kapitalen. Udover denne ordning er det ret svævende, hvorledes rammerne skal sikres overholdt, men måske heller ikke så stort et problem, for regering og fagbevægelse overlader stiltiende det endegyldige løntryk til de 200.000 arbejdsløse. I følge »Børsen« d. 13.6.77. er reallønnen faldet ca. 1.5\% fra marts 1976 til marts 1977, eller som bladet så forsigtigt udtrykker det: »Man kan roligt karakterisere opbremsningen i lønstigningen som betydelig «.

De sidste års megen sludder om frisættelse af ressourcer og om fremskyndelse af strukturændringer er nu hørt op: Ressourcerne er blevet frisat, nu skal deres pris bare sættes ned. 


\section{Slutbemærkninger}

Vi kan således sammenfatte vores undersøgelse i følgende punkter, der beskriver en central del af forholdet mellem $\varnothing$ konomi og politik i den danske reformkapitalisme.

Vores resultater er:

- at grænserne for den keynesianske regulering modificeres eller forskydes gennem eksistensen af den kooperative fagforeningspolitik, således at sammenbruddet i denne reguleringsform først indtræder med krisen

- at det følgelig ikke er den fulde beskæftigelse og den ekspansive finanspolitik, men derimod arbejdsløsheden og krisen, der umiddelbart frembringer nødvendigheden af lønindgreb (dette i modsætning til Semmler og Hoffmanns argumentation)

- at en indkomstpolitik, formet som aktiv statslig intervention i løndannelsen, først bliver en nødvendighed i en situation, hvor den kooperative fagforeningspolitik ikke længere fungerer, og hvor den faldende profitabilitet ved overgangen til den nuværende krise tvinger til en reduktion af produktionsomkostningerne - og da først og fremmest lønomkostningerne.

- at efterkrigstiden har været karakteriseret af den paradoksale situation, at netop udviklingen af de politiske forhold, der i den borgerlige indkomstpolitiske debat til stadighed bliver fremhævet som afgørende forudsætning for en effektiv indkomstpolitisk styring, netop har gjort en sådan styring overflødig.

- at den kooperative fagforeningspolitik og den statslige rammestyring udvikler sig konjunkturafhængigt, således at den først kan udfolde sig fuldt ud i et langvarigt opsving, men ødelægges i krisen. Betingelserne for deres genoplivelse forbliver imidlertid i vid udstrækning intakte under krisen, idet indgrebene under kriseforløbet indpasses i den historiske form, der formelt fastholder og understreger arbejdsmarkedets autonomi og kontraktforholdets gyldighed.

- at den arbejdsdeling, som Socialdemokratiet og fagbevægelsen videreudviklede i løbet af tresserne, muliggjorde akutte statsindgreb mod lønnen, forudsat at regeringen var socialdemokratisk, således som det også i almindelighed fremhæves i den indkomstpolitiske debat. Det afgørende er imidlertid, at krisen tendentielt ophæver arbejdsdelingen, hvorved der skabes en gensidig ansvarlighed for den $\emptyset$ konomiske politik mellem den faglige og den politiske arbejderbevægelse. De sidste års statslige indkomstpolitik fremkalder dermed en række problemer. Fagbevægelsen bliver gjort ansvarlig - ikke bare for en akut krisepolitik, som skal fordele et momentant tilbageslags virkningen som i tresserne, men for en eksplicit lønstyring, der 
i realiteten lader hånt om autonomien på arbejdsmarkedet og tendentielt forhindrer fagbevægelsen i at opfylde sin funktion som varetager af arbejdernes revenukildeinteresser

- at denne udvikling i første omgang har ført til en generel politisk og faglig passivitet og opbakning bag de reformistiske positioner. Og at den kun på lang sigt, hvis krisen varer ved og opsvinget udebliver, rummer mulighed for en opbrydning i disse positioner

- at Socialdemokratiet og fagbevægelsen i forbindelse med et evt. kommende opsving efter års lønstyring og krise igen vil søge mod positioner, der muliggør en rammestyring med kooperativ fagforeningspolitik, evt. suppleret med nye styringsinstrumenter i form af $\varnothing \mathrm{D}$, fondsdannelser osv.

- og at diskussionen af kampen mod reformismen derfor må tage sit udgangspunkt - ikke i den nuværende indkomstpolitisk uhyrlighed eller det kommende indgrebs svigagtige karakter - men i unders $\varnothing$ gelsen af udviklingsbetingelserne for denne kamp, dvs. af reformismens materielle grundlag, en velfungerende akkumulationsproces. 


\section{BILAG}

Vi har i Bilagstabellen angivet det basismateriale, vi har arbejdet med i beregningerne af kapitalrentabiliteten og dens elementer og i beregningerne af produktivitets- og reallønsudvikling.

Kilderne til basismaterialet er: Statistisk oversigt 1948-1959; Statistisk ti-årsoversigt 1967, 1970, 1973, 1975 og 1977; Statistiske Efterretninger nr. 1, 2 og 31978 samt Index og konjunkturoversigt i Erhvervsbladet fra 16/2 1978 .

\section{Kommentarer til de enkelte beregninger:}

Produktivitetsudviklingen er beregnet som væksten i forholdet mellem industriens bruttofaktorindkomst i 1955-priser og det udførte antal arbejdstimer i industrien. P.g.a. ændrede opgørelsesmetoder - jvf. Statistisk ti-års oversigt 1975, s. 25 - er væksten i arbejdstimer fra 1964 til 1965 kunstig stor, og den meget lave vækst i produktiviteten derfor ikke svarende til den faktiske. Beregnet efter samme opgørelsesmetoder som 1964 er væksten i 1965 i produktiviteten 6,3\%. Den samme statistiske ændring smitter også af på lønsummens størrelse og de deraf afledte indikatorer og på kapitalintensiteten og -rentabiliteten, hvor specielt udviklingen fra 1964 til 1965 er influeret heraf.

Investeringerne i driftsmidler omfatter maskiner, værktøj og eksternt transportmateriel, samt det der tidligere opgjordes som andet materiel.

Deflatoren, der bruges til beregningerne af investeringerne (og kapitalstocken) i 1955-priser, er udregnet på basis af Nationalregnskabsopgørelserne over bruttoinvesteringer i maskiner, transportmidler m.v. i henholdsvis 1955-priser og løbende priser.

Kapitalstocken, der udtrykker den beregnede teknisk- økonomiske værdi af industriens driftsmiddelanlæg, er beregnet med udgangspunkt i den metode, der anvendes hos C.E. Sørensen i »Kreditmarked og industriens ekspansion«, Kbh. 1971. For at eliminere inflationsudviklingen er beregningerne her foretaget som fastprisberegninger. Beregningerne af kapitalstocken i et givet år er her foretaget som:

$$
K_{n}=\left(\sum_{i=n-4}^{i=n} I \times d_{n}\right)+1 / 2\left(\sum_{i=n-9}^{i=n-5} I \times d_{n-5}\right)
$$

Kapitalstocken i 1965 i faste priser fås altså som summen af investeringerne i perioden 1961-65 i løbende priser deflateret med 1965-deflatoren plus den hal- 


\begin{tabular}{|c|c|c|c|c|c|c|c|c|c|}
\hline År & $\begin{array}{r}\mathrm{BFI} \mathrm{i} \\
\mathrm{Yi}\end{array}$ & $\begin{array}{l}\text { lustrien } \\
\text { nio. }\end{array}$ & $\begin{array}{c}\text { Arbejds- } \\
\text { timer i } \\
\text { industrien } \\
\text { L } \\
\text { i mio }\end{array}$ & $\begin{array}{c}\text { Arbejds- } \\
\text { produkti- } \\
\text { vitet } \\
\mathrm{Y}: \mathrm{L}\end{array}$ & $\begin{array}{l}\% \text {-vir.- } \\
\text { vækst i } \\
\mathrm{Y}_{\mathrm{f}}: \mathrm{L}\end{array}$ & $\begin{array}{l}\text { Lønsum i } \\
\text { mio. } \\
\text { W }\end{array}$ & $\begin{array}{c}\text { Løn- } \\
\text { kvote } \\
\mathrm{W}: \mathrm{Y}= \\
\mathrm{W}\end{array}$ & $\begin{array}{c}\text { Profit- } \\
\text { kvote } \\
1-\mathrm{w}\end{array}$ & Deflator \\
\hline 1949 & 3485 & 4257 & 515.0 & 8.266 & - & 1994 & 0.572 & 0.428 & \\
\hline 1950 & 4108 & 4772 & 555.1 & 8.597 & 4.0 & 2296 & 0.559 & 0.441 & \\
\hline 1951 & 4349 & 4818 & 550.6 & 8.750 & 1.8 & 2540 & 0.584 & 0.416 & \\
\hline 1952 & 4319 & 4586 & 523.4 & 8.762 & 0.1 & 2649 & 0.613 & 0.387 & \\
\hline 1953 & 4719 & 4750 & 527.7 & 9.001 & 2.4 & 2829 & 0.599 & 0.401 & 1.0028 \\
\hline 1954 & 5107 & 5150 & 548.4 & 9.391 & 4.3 & 3073 & 0.602 & 0.398 & 1.0234 \\
\hline 1955 & 5244 & 5244 & 540.7 & 9.699 & 3.3 & 3205 & 0.611 & 0.389 & 1.0000 \\
\hline 1956 & 5467 & 5313 & 528.7 & 10.049 & 3.6 & 3396 & 0.621 & 0.379 & 0.9506 \\
\hline 1957 & 6078 & 5638 & 542.1 & 10.400 & 3.5 & 3684 & 0.606 & 0.394 & 0.9151 \\
\hline 1958 & 6451 & 5873 & 542.6 & 10.824 & 4.1 & 3879 & 0.601 & 0.399 & 0.9098 \\
\hline 1959 & 7374 & 6578 & 572.4 & 11.492 & 6.2 & 4347 & 0.590 & 0.410 & 0.9046 \\
\hline 1960 & 8362 & 7266 & 611.7 & 11.878 & 3.4 & 4951 & 0.592 & 0.408 & 0.8835 \\
\hline 1961 & 9213 & 7657 & 605.9 & 12.637 & 6.4 & 5543 & 0.602 & 0.398 & 0.8445 \\
\hline 1962 & 10529 & 8319 & 623.1 & 13.351 & 5.7 & 6276 & 0.596 & 0.404 & 0.8161 \\
\hline 1963 & 10838 & 8425 & 607.4 & 13.871 & 3.9 & 6694 & 0.618 & 0.382 & 0.7723 \\
\hline 1964 & 12302 & 9415 & 622.2 & 15.132 & 9.1 & 7475 & 0.608 & 0.392 & 0.7554 \\
\hline 1965 & 13586 & 10036 & 654.5 & 15.334 & 1.3 & 8683 & 0.639 & 0.361 & 0.7144 \\
\hline 1966 & 14406 & 10243 & 629.4 & 16.274 & 6.1 & 9588 & 0.666 & 0.334 & 0.6824 \\
\hline 1967 & 15240 & 10612 & 588.6 & 18.029 & 10.8 & 10092 & 0.662 & 0.338 & 0.6675 \\
\hline 1968 & 16868 & 11355 & 570.6 & 19.900 & 10.4 & 10939 & 0.649 & 0.351 & 0.6365 \\
\hline 1969 & 19128 & 12809 & 589.2 & 21.740 & 9.2 & 12568 & 0.657 & 0.343 & 0.6249 \\
\hline 1970 & 21777 & 13550 & 578.6 & 23.419 & 7.7 & 13889 & 0.638 & 0.362 & 0.5934 \\
\hline 1971 & 23158 & 14024 & 554.1 & 25.310 & 8.1 & 15275 & 0.660 & 0.340 & 0.5580 \\
\hline 1972 & 26189 & 15125 & 548.5 & 27.575 & 8.9 & 16955 & 0.647 & 0.353 & 0.5133 \\
\hline 1973 & 29600 & 15725 & 540.2 & 29.110 & 5.6 & 19626 & 0.663 & 0.337 & 0.4875 \\
\hline 1974 & 32500 & 16025 & 526.5 & 30.437 & 4.6 & 23245 & 0.715 & 0.285 & 0.4036 \\
\hline 1975 & 34919 & 14925 & 455.1 & 32.795 & 7.7 & 24484 & 0.701 & 0.299 & 0.3508 \\
\hline 1976 & 40600 & 16140 & 464.0 & 34.784 & 6.1 & 27562 & 0.679 & 0.321 & 0.3361 \\
\hline 1977 & & & & & & & & & \\
\hline
\end{tabular}




\begin{tabular}{|c|c|c|c|c|c|c|c|c|c|}
\hline \multicolumn{2}{|c|}{$\begin{array}{l}\text { Inversteringer } \\
\text { i driftsmidler i } \\
\text { mio. }\end{array}$} & \multirow{2}{*}{$\begin{array}{c}\text { Kapital- } \\
\text { stock i } \\
-55 \text { pris. } \\
\text { i mio. } \\
\mathrm{K}_{\mathrm{f}}\end{array}$} & \multirow{2}{*}{$\begin{array}{c}\begin{array}{c}\text { Kapital- } \\
\text { inten- } \\
\text { sitet }\end{array} \\
\mathrm{K}_{\mathrm{f}}: \mathrm{L}\end{array}$} & \multirow{2}{*}{$\begin{array}{c}\text { Kapital- } \\
\text { renta- } \\
\text { bilitet } \\
\text { pi }\end{array}$} & \multirow{2}{*}{$\begin{array}{l}\text { Timeløn } \\
\text { i indust. } \\
\text { og hånd- } \\
\text { værk i } \\
\text { kr. }\end{array}$} & \multirow{2}{*}{$\begin{array}{c}\text { Forbru- } \\
\text { gerpris- } \\
\text { index } \\
-64=100\end{array}$} & \multirow{2}{*}{$\begin{array}{c}\text { Real- } \\
\text { løns- } \\
\text { index } \\
-64=100\end{array}$} & \multirow[t]{2}{*}{$\begin{array}{l}\text { \%-vir. } \\
\text { vækst i } \\
\text { realløn }\end{array}$} & \multirow[t]{2}{*}{ År } \\
\hline lb.pris. & -55 pris. & & & & & & & & \\
\hline & & - & - & - & & & & & 1949 \\
\hline & & 1763 & 3.176 & 1.194 & & & & & 1950 \\
\hline & & 1735 & 3.151 & 1.155 & & & & & 1951 \\
\hline & & 1695 & 3.238 & 1.023 & & & & & 1952 \\
\hline 352 & 353 & 1918 & 3.635 & 0.993 & 4.09 & & & & 1953 \\
\hline 393 & 402 & 2057 & 3.751 & 0.996 & 4.28 & & & & 1954 \\
\hline 382 & 382 & 2237 & 4.137 & 0.912 & 4.48 & & & & 1955 \\
\hline 338 & 321 & 2219 & 4.197 & 0.907 & 4.83 & & & & 1956 \\
\hline 458 & 419 & 2317 & 4.274 & 0.959 & 5.10 & & & & 1957 \\
\hline 513 & 467 & 2520 & 4.644 & 0.930 & 5.31 & & & & 1958 \\
\hline 619 & 560 & 2787 & 4.869 & 0.968 & 5.71 & 80 & 81 & & 1959 \\
\hline 771 & 681 & 3176 & 5.192 & 0.933 & 6.08 & 82 & 84 & 3.8 & 1960 \\
\hline 901 & 761 & 3676 & 6.067 & 0.829 & 6.82 & 85 & 91 & 8.2 & 1961 \\
\hline 1096 & 894 & 4063 & 6.521 & 0.827 & 7.52 & 92 & 93 & 1.9 & 1962 \\
\hline 1006 & 777 & 4341 & 7.147 & 0.741 & 8.12 & 96 & 96 & 3.6 & 1963 \\
\hline 1236 & 934 & 4829 & 7.761 & 0.764 & 8.82 & 100 & 100 & 4.3 & 1964 \\
\hline 1388 & 992 & 5212 & 7.963 & 0.695 & 9.86 & 106 & 105 & 5.4 & 1965 \\
\hline 1314 & 897 & 5499 & 8.737 & 0.622 & 11.06 & 114 & 110 & 4.3 & 1966 \\
\hline 1320 & 881 & 5773 & 9.808 & 0.621 & 12.10 & 122 & 112 & 2.3 & 1967 \\
\hline 1228 & 782 & 5825 & 10.209 & 0.684 & 13.53 & 132 & 116 & 3.3 & 1968 \\
\hline 1573 & 983 & 6156 & 10.448 & 0.714 & 15.08 & 136 & 126 & 8.2 & 1969 \\
\hline 1925 & 1142 & 6379 & 11.025 & 0.769 & 16.77 & 145 & 131 & 4.3 & 1970 \\
\hline 2060 & 1149 & 6584 & 11.882 & 0.724 & 19.30 & 154 & 142 & 8.3 & 1971 \\
\hline 2159 & 1108 & 6682 & 12.182 & 0.799 & 21.54 & 164 & 149 & 4.8 & 1972 \\
\hline 2739 & 1335 & 7161 & 13.256 & 0.740 & 24.85 & 179 & 157 & 5.7 & 1973 \\
\hline 3183 & 1285 & 7002 & 13.299 & 0.652 & 29.74 & 207 & 163 & 3.5 & 1974 \\
\hline 2966 & 1040 & 6782 & 14.901 & 0.658 & 35.44 & 226 & 178 & 9.1 & 1975 \\
\hline \multirow[t]{2}{*}{3435} & 1155 & 7129 & 15.364 & 0.727 & 39.50 & 247 & 181 & 2.0 & 1976 \\
\hline & & & & & $43.39 *$ & 274 & $180^{*}$ & $\div 0.9^{*}$ & 1977 \\
\hline
\end{tabular}


ve sum af investeringerne i perioden 1956-60 deflateret med 1960-deflatoren. Da der imidlertid ikke er sammenlignelighed mellem investeringsopgørelserne før og efter 1953 har denne metode kun kunnet anvendes for perioden 1962 og frem. For perioden 1950-61 er anvendt fastprisberegningerne på C.E. Sørensens kapitalstockopgørelse hos J. Brinch i »Kapitalakkumulationen i Danmark efter 1940, II«, Kbh. 1975 - jvf. i øvrigt bemærkningerne til beregningsproblemerne samme sted.

Kapitalrentabiliteten er beregnet efter flg. formel: $\mathrm{pi}=\mathrm{Y} / \mathrm{L}(1-\mathrm{w}): \mathrm{K} / \mathrm{L}$.

Reallønsindexet er beregnet på basis af den gennemsnitlige timeløn for samtlige arbejdere i industri og håndværk deflateret med forbrugerprisindexet. Indexet er beregnet med basis i 1964. For 1977 er timelønnen estimeret på basis af udviklingen fra 2. kvartal 1976 til 2. kvartal 1977.

For en række af de opgjorte størrelser og mål gælder det, at der i den omhandlede periode er ændret opgørelsesmetode og optællingsgrundlag. Dette giver naturligvis en række formelle, statistiske problemer ved sammenligninger på forskellige tidspunkter. Vores formål med beregningerne overhovedet $\mathrm{i}$ tabellen har været at skabe grundlaget for et overblik over de langsigtede $u d$ viklingstendenser, således som de kan udtrykkes kvantitativt, og ikke at opnå helt statistisk eksakte opgørelser over værdierne i de enkelte år. Vi har derfor i hvert enkelt tilfælde valgt at bruge de nyeste, reviderede tal for at få så lange tidsrækker som muligt opgjort på samme basis.

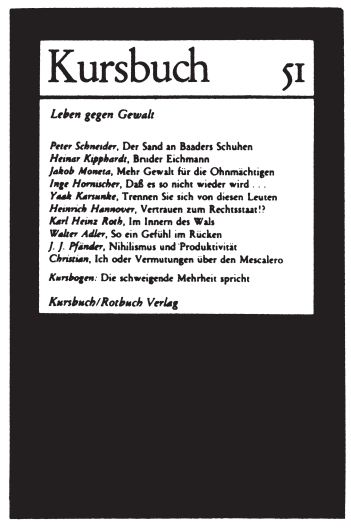

Løssalgspris: 28,- kr. Abonnementspris: 22,- kr. Distribution: KURASJE

\section{Kursbuch 52: Utopien - Lust an der Zukunft}

Stichworte zum Inhalt:

Unter welchen Bedingungen enstehen Utopien

Was ist utopisches Denken ohne den Glauben an den Fortschritt?

Bilderverbot in der Sozialdemokratie

Die Zukunft der Arbeit

Schule und Universität: utopische Formen des Lehrens und Lernens

Möglichkeiten einer anderen Technologie

Zukunftswerkstätten

Wie wollen wir wohnen?

Die Zukunft der Treue

Was wurde aus den Utopien der Neuen

Linken?

Die Lust am Untergang

Udkommer juni 1978. 